Prepared in cooperation with the Pioneer Valley Planning Commission, the U.S. Environmental Protection Agency, and the Massachusetts Department of Environmental Protection

\title{
Assessment of the Presence of Sewage in the Mill River Under Low-Flow Conditions, Springfield, Massachusetts, 2010-11
}

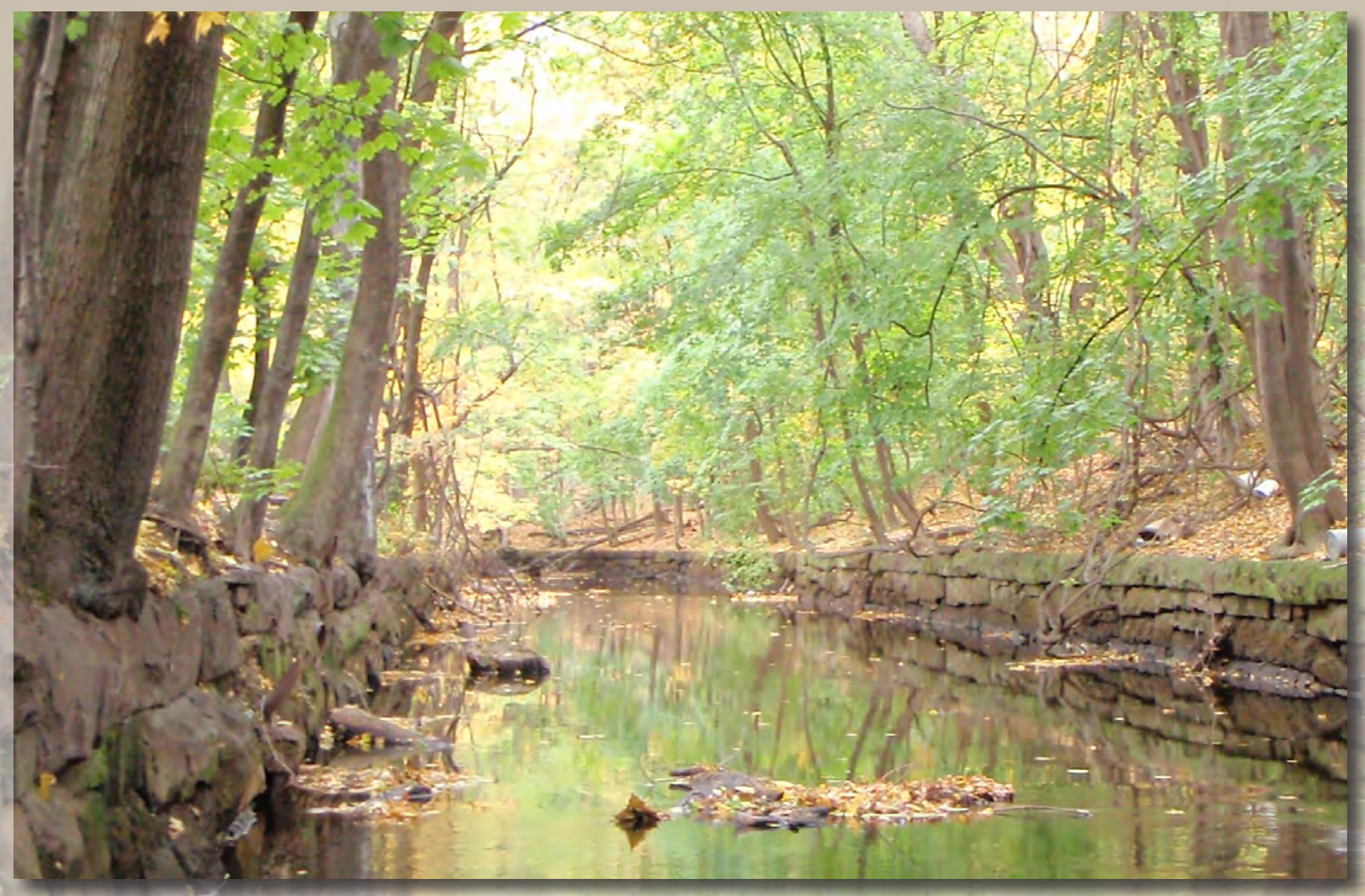

Scientific Investigations Report 2019-5027

U.S. Department of the Interior U.S. Geological Survey 
Cover. The Mill River in Springfield, Massachusetts, viewed looking upstream from sample site 01178000, a discontinued streamgage just upstream from the Hancock Street bridge. Photograph by Andrew J. Massey, U.S. Geological Survey. 


\section{Assessment of the Presence of Sewage in the Mill River Under Low-Flow Conditions, Springfield, Massachusetts, 2010-11}

By Andrew J. Massey, Marcus C. Waldron, R. Jean Tang, and Thomas G. Huntington

Prepared in cooperation with the Pioneer Valley Planning Commission, the U.S. Environmental Protection Agency, and the

Massachusetts Department of Environmental Protection

Scientific Investigations Report 2019-5027 


\title{
U.S. Department of the Interior \\ DAVID BERNHARDT, Secretary
}

\author{
U.S. Geological Survey \\ James F. Reilly II, Director
}

U.S. Geological Survey, Reston, Virginia: 2019

For more information on the USGS - the Federal source for science about the Earth, its natural and living resources, natural hazards, and the environment-visit https://www.usgs.gov or call 1-888-ASK-USGS.

For an overview of USGS information products, including maps, imagery, and publications,

visit https://store.usgs.gov.

Any use of trade, firm, or product names is for descriptive purposes only and does not imply endorsement by the U.S. Government.

Although this information product, for the most part, is in the public domain, it also may contain copyrighted materials as noted in the text. Permission to reproduce copyrighted items must be secured from the copyright owner.

Suggested citation:

Massey, A.J., Waldron, M.C., Tang, R.J., and Huntington, T.G., 2019, Assessment of the presence of sewage in the Mill River under low-flow conditions, Springfield, Massachusetts, 2010-11: U.S. Geological Survey Scientific Investigations Report 2019-5027, 18 p., https://doi.org/10.3133/sir20195027.

ISSN 2328-0328 (online) 


\section{Acknowledgments}

The authors gratefully acknowledge the advice and support of Chris Curtis and Anne Capra from the Pioneer Valley Planning Commission and the assistance of Josh Schimmel from the Springfield Water and Sewer Commission who generously shared information about the location of sewer infrastructure and other background data and assisted in sampling efforts. The authors thank Oscar Pancorbo and the other helpful and professional staff members of the Wall Experiment Station of the Massachusetts Department of Environmental Protection for sample analysis and also thank Mary Gowins and Kim Campo of the U.S. Geological Survey for assistance in field data collection. 



\section{Contents}

Acknowledgments ……...................................................................................................................

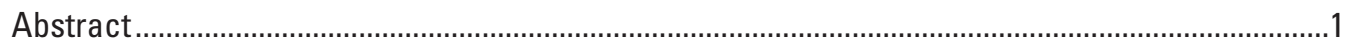

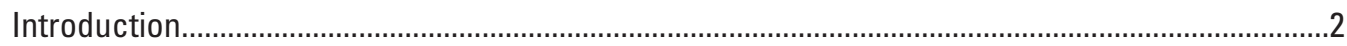

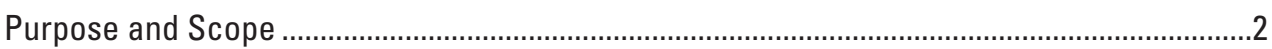

Hydrologic Setting of the Mill River, Springfield, Massachusetts.............................................2

Potential Sources of Contamination in the Mill River Watershed ............................................

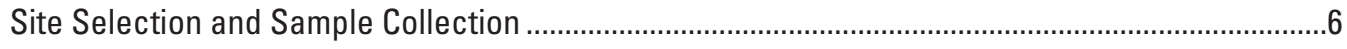

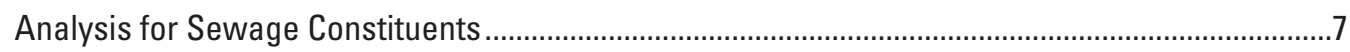

Pharmaceutical Compounds...................................................................................................

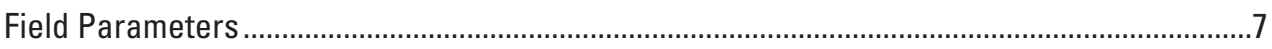

Fecal Coliform Bacteria and Host-Specific Genetic Markers.....................................................7

Fluorescent Whitening Agents ..................................................................................................

Quality-Assurance and Quality-Control Procedures ....................................................................

Results for Field Parameters and Wastewater Constituents ..............................................................

Field Parameters ...........................................................................................................

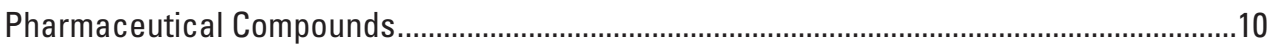

Fecal Coliform Bacteria and Host-Specific Genetic Markers..............................................10

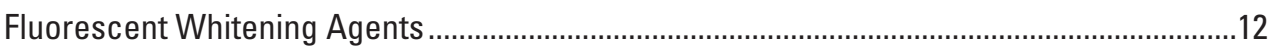

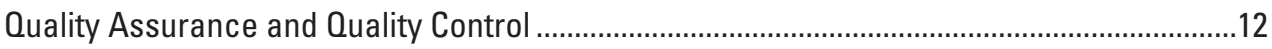

Discussion of Wastewater Constituents in the Mill River..............................................................15

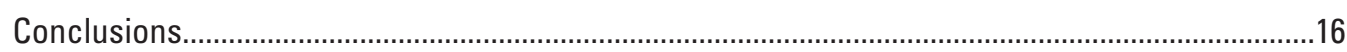

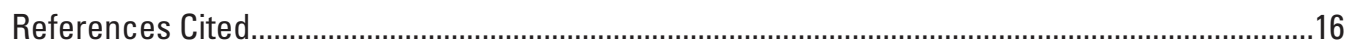

\section{Figures}

1. Map showing the Mill River watershed in central Massachusetts and the location of the study area, land use, and sample sites on the Mill River, Springfield,

Massachusetts...........................................................................................................

2. Photographs showing the Mill River in Springfield, Massachusetts. ...............................4

3. Photograph showing resident geese at Watershops Pond near Springfield College and Wesson Park, Springfield, Massachusetts ...

4. Graph showing precipitation near the Mill River recorded at Westover Air Reserve Base, Massachusetts, sample dates for the period from July 1, 2010, through November 30, 2010, daily streamflow at the nearby Mill River in Northampton, Massachusetts (USGS streamgage 01171500), during this period, and historical mean daily streamflow for the period November 1938 to September 2014

5. Photograph showing green algae in Mill River water spilling from Watershops Pond impoundment under the mill at Watershops Pond, Springfield, Massachusetts, September 1, 2010

6. Bar graph showing Escherichia coli concentrations measured in samples of Mill River water, Springfield, Massachusetts, collected from three sites and at four times during summer and fall 2010.

7. Bar graph showing enterococci concentrations measured in samples of Mill River water, Springfield, Massachusetts, collected from three sites and at four times during summer and fall 2010 


\section{Tables}

1. Human-health pharmaceutical compounds measured in water from the Mill River at three sites from Watershops Pond to the mouth above the Connecticut River, Springfield, Massachusetts, 2010-11

2. Field parameters measured in river water and bacteria results from samples collected intermittently at four sites at the Mill River, Springfield, Massachusetts, from Watershops Pond to the mouth above the Connecticut River, July 2010 through March 2011

3. Concentrations of pharmaceutical compounds measured in samples from three sites at the Mill River, Springfield, Massachusetts, from Watershops Pond to the mouth above the Connecticut River, about monthly from July through

November 2010.

4. Results of analyses performed by the Senator William X. Wall Experiment Station for detection of human-specific bacteria and anthropogenic materials in the Mill River, Springfield, Massachusetts, measured at three sites from Watershops Pond to the mouth above the Connecticut River, July through November 2010.

5. A, Concentrations of pharmaceutical compounds in quality-assurance samples and $B$, ranges of percent recoveries of known concentrations of compounds added to samples. 


\section{Conversion Factors}

U.S. customary units to International System of Units

\begin{tabular}{lcl} 
& Multiply & \multicolumn{1}{c}{ To obtain } \\
\hline inch (in.) & Length & \\
foot (ft) & 2.54 & centimeter $(\mathrm{cm})$ \\
mile (mi) & 0.3048 & meter $(\mathrm{m})$ \\
\hline & 1.609 & kilometer $(\mathrm{km})$ \\
\hline square mile $\left(\mathrm{mi}^{2}\right)$ & Area & \\
\hline & 2.590 & square kilometer $\left(\mathrm{km}^{2}\right)$ \\
\hline gallon (gal) & Volume & \\
\hline & 3.785 & liter $(\mathrm{L})$ \\
\hline cubic foot per second $\left(\mathrm{ft}^{3} / \mathrm{s}\right)$ & Flow rate & \\
million gallons per year $(\mathrm{Mgal} / \mathrm{yr})$ & 3,785 & cubic meter per year $\left(\mathrm{m}^{3} / \mathrm{yr}\right)$ \\
\hline
\end{tabular}

Temperature in degrees Celsius $\left({ }^{\circ} \mathrm{C}\right)$ may be converted to degrees Fahrenheit $\left({ }^{\circ} \mathrm{F}\right)$ as ${ }^{\circ} \mathrm{F}=\left(1.8 \times{ }^{\circ} \mathrm{C}\right)+32$.

\section{Datum}

Horizontal coordinate information is referenced to the North American Datum of 1983 (NAD 83).

\section{Supplemental Information}

Specific conductance is given in microsiemens per centimeter at 25 degrees Celsius $\left(\mu \mathrm{S} / \mathrm{cm}\right.$ at $\left.25^{\circ} \mathrm{C}\right)$.

Concentrations of chemical constituents in water are given in micrograms per liter $(\mu \mathrm{g} / \mathrm{L})$.

Concentrations of bacteria in water are given in colony-forming units per 100 milliliters (CFU/100 mL).

Filter-mesh sizes are given in micrometers $(\mu \mathrm{m})$.

Time is reported in military time format as hours and minutes. 


\section{Abbreviations}

$\begin{array}{ll}\text { CSO } & \text { combined sewer overflow } \\ \text { CSS } & \text { combined sewer system } \\ \text { E. Coli } & \text { Escherichia coli } \\ \text { EPA } & \text { U.S. Environmental Protection Agency } \\ \text { EWI } & \text { equal width increment } \\ \text { FWA } & \text { fluorescence whitening agent } \\ \text { MassDEP } & \text { Massachusetts Department of Environmental Protection } \\ \text { NWOL } & \text { National Water Quality Laboratory } \\ \text { OB } & \text { optical brightener } \\ \text { PCR } & \text { polymerase chain reaction } \\ \text { OA } & \text { quality assurance } \\ \text { OC } & \text { quality control } \\ \text { RL } & \text { analytical reporting level } \\ \text { TCRTWI } & \text { Tri-State Connecticut River Targeted Watershed Initiative } \\ \text { USGS } & \text { U.S. Geological Survey } \\ \text { WES } & \text { Wall Experiment Station }\end{array}$




\title{
Assessment of the Presence of Sewage in the Mill River Under Low-Flow Conditions, Springfield, Massachusetts, 2010-11
}

\author{
By Andrew J. Massey, ${ }^{1}$ Marcus C. Waldron, ${ }^{1}$ R. Jean Tang, ${ }^{2}$ and Thomas G. Huntington ${ }^{1}$
}

\section{Abstract}

The U.S. Geological Survey, in cooperation with the Pioneer Valley Planning Commission, the U.S. Environmental Protection Agency, and the Massachusetts Department of Environmental Protection Senator William X. Wall Experiment Station, assessed the presence of 14 commonly used human-health pharmaceutical compounds, fecal indicator bacteria, and other man-made compounds indicative of the presence of human sewage in the lower reach of the Mill River near its confluence with the Connecticut River in Springfield, Massachusetts. The study was part of the Tri-State Connecticut River Targeted Watershed Initiative and involved the collection and analysis of raw river water at three sites along the reach, extending from Watershops Pond to the mouth, over the course of a low-flow period, July through November 2010. Previous studies in the region indicated that nonpoint or undocumented sources of wastewater contributed a variety of organic contaminants and potentially harmful bacteria to rivers under both high- and low-flow conditions. Additional samples, including a raw sewage sample collected near a Mill River combined sewer overflow during a non-overflow period, were collected in March 2011.

The study was designed to determine if city sewage or other domestic sources of wastewater were entering the river within this reach during low-flow conditions. No definitive evidence of sewage was measured in Mill River water samples collected during the study period. Fecal indicator bacteria, including Escherichia coli (E. coli) and enterococci bacteria, were detected in all Mill River water samples. In the DNA analysis of enterococci cultures from the Mill River, samples generally tested negative for the Enterococcus faecium (esp) human-specific genetic marker, whereas the raw sewage

${ }^{1}$ U.S. Geological Survey.

${ }^{2}$ Massachusetts Department of Environmental Protection. sample tested positive. Samples also generally tested negative in the human-specific rDNA marker assay for the anaerobic bacterium Bacteroidetes. Samples tested negative in 2010 for two Bacteroidetes human-specific genetic markers, HF134 and HF183, except samples from near the mouth of the Mill River, which tested positive. Samples collected in March 2011 from all three measurement sites tested positive for both markers. The results of bacterial analyses suggest that the fecal bacteria in summer and fall months are most likely of animal origin rather than human. Despite the urban setting, long history of development, and many potential sources of man-made contamination in the Mill River, none of the 12 water samples collected during the study contained targeted pharmaceutical compounds at concentrations greater than the analytical reporting levels. Other man-made compounds, like fluorescent whitening agents, were measured and detected in samples at low concentrations 4 out of 5 times the samples were collected; however, the other lines of evidence do not support a sewer source but rather other nonpoint sources upstream in the watershed.

The results of this study do not support the hypothesis that aging sewer lines or combined sewer overflow infrastructure leak into the Mill River as tested during the low-flow conditions during sampling for this study. None of the results from Mill River samples offer conclusive evidence of the presence of sewage. Some low-level detections of pharmaceutical compounds, other man-made chemicals, and bacteria suggest an upstream, nonpoint source.

A single raw sewage sample was collected, diluted, and examined for comparison with Mill River water samples and to ensure that the analytical methods could detect typical wastewater constituents. High levels of bacteria were measured, and low levels of three anthropogenic pharmaceutical compounds were detected, confirming the effectiveness of the sub-part-per-million method. The concentration of fluorescent whitening agent-1 in the sewage sample was 90,000 times greater than the median concentration in the Mill River samples. 


\section{Introduction}

The city of Springfield, Massachusetts, located along the lower Mill River, has a long history of development. The city includes many underground sewers, and residential neighborhoods and suburbs have developed around the headwater reaches. The watercourse is an example of the highly urbanized tributaries typically found in and near cities along the main stems of major rivers in the eastern United States. Previous studies in the region indicated that nonpoint or undocumented sources of wastewater contributed a variety of organic contaminants and potentially harmful bacteria to rivers under both high- and low-flow conditions (Poiger and others, 1996; Breault and others, 2002; Barnes and others, 2008; Massey and Waldron, 2011). Aging public works infrastructure, high-density, onsite septic systems, and various nonpoint sources are among several possible sources of contaminants and bacteria.

The causes and sources of bacteria and contaminant loading from the surrounding landscape to the Connecticut River are not completely understood. One substantial knowledge gap is the extent to which inflows from urbanized tributaries, which may contain flows from relic and illicit sewer connections and various nonpoint sources, contribute to water-quality impairment during low-flow conditions. The Mill River component (this study) of the Tri-State Connecticut River Targeted Watershed Initiative (TCRTWI) was designed to quantify indicators of sewage and fecal bacteria in the most urbanized reach of the river during low-flow hydrologic conditions.

A longitudinal sampling approach was implemented as a first step to identify any in-river water-quality impairment during a low-flow period. Multiple sites were sampled from July through November 2010 to help geographically identify source areas of water-quality impairment. The objective of this study was to determine whether a suite of 14 commonly used human-health pharmaceutical compounds, fecal indicator bacteria, and other man-made materials indicative of human sewage could be detected in a reach of the Mill River under low-flow conditions. Another objective was to determine the source (human or animal) of fecal coliform bacteria found in the Mill River.

This study, a component of the TCRTWI, was designed and carried out by the U.S. Geological Survey (USGS) in cooperation with the Pioneer Valley Planning Commission and the U.S. Environmental Protection Agency (EPA). The TCRTWI is a cooperative project, funded by more than a dozen local organizations, that addresses some of the most important water-quality impairments in the Connecticut River watershed, including combined sewer overflows (CSOs), episodic river-bank erosion, increased threats to sources of public water supplies, and nutrient loading by runoff from agricultural operations and other nonpoint sources. Because of the presence of CSOs, several sections of the Connecticut River do not support recreational use designation (Connecticut Department of Environmental Protection, 2011).

\section{Purpose and Scope}

This report documents the Mill River component of the TCRTWI. The report describes the methods of selecting sites, measuring and processing field observations, collecting and analyzing water samples, and applying quality-assurance (QA) and quality-control (QC) procedures. Results are presented for field parameters, pharmaceutical compounds, fecal coliform bacteria and host-specific genetic markers, and fluorescent whitening agents. The results are discussed as evidence in the assessment of the presence of sewage in the Mill River during the low-flow study period. All data generated or analyzed during this study are included in the main text of this publication.

\section{Hydrologic Setting of the Mill River, Springfield, Massachusetts}

The Mill River is a tributary to the Connecticut River on the eastern slope of the Pioneer Valley in south-central Massachusetts (fig. 1). The Mill River drains a small (33-squaremile) watershed with diverse land use. Land use in the watershed ranges from mixed rural, agricultural, and forested land in the headwaters to suburban and dense urban development along the lower reaches down to the confluence with the Connecticut River at Springfield, Massachusetts. Watershops Pond, the impoundment formed by the Springfield Armory Watershops mill complex, marks the transition to the heavily developed urban reach of the Mill River along the final mile of the river. The pond is bordered by a narrow, wooded buffer along most of the shoreline; however, dense housing developments, schools, a large hospital, a cemetery, businesses, and industrial and other urban infrastructure are near the river corridor.

The lower Mill River has played an important role in the cultural and hydrologic history of Springfield. Its steep gradient, abundant water power, and proximity to the developing downtown made it an ideal location for mills and other heavy industry such as the Springfield Armory Watershops, which dammed the river at Allen Street. The Watershops were constructed in 1855 as the mill counterpart to the Springfield Armory "Hilltops," the primary campus of the Nation's first national armory, on State Street (fig. 2) (Bauer, 1975).

During the 19th and early 20th centuries it was common for untreated sewage to be discharged directly to the river. Remnants of outfall pipes remain along the man-made hardened walls of the river below Watershops Pond. Many improvements have been made to sewer and water infrastructure in Springfield, but at the time of this study (2010), the sewer system near the lower Mill River was still a combined sewer system (CSS) where up to 7 CSOs discharged approximately 3.2 million gallons per year (Mgal/yr) directly to the lower Mill River during intense rain or snowmelt events (Pioneer Valley Planning Commission, 2005b). The wastewater treatment plant that serves the sewered, urbanized part of the Mill River watershed is outside of the Mill River watershed, 


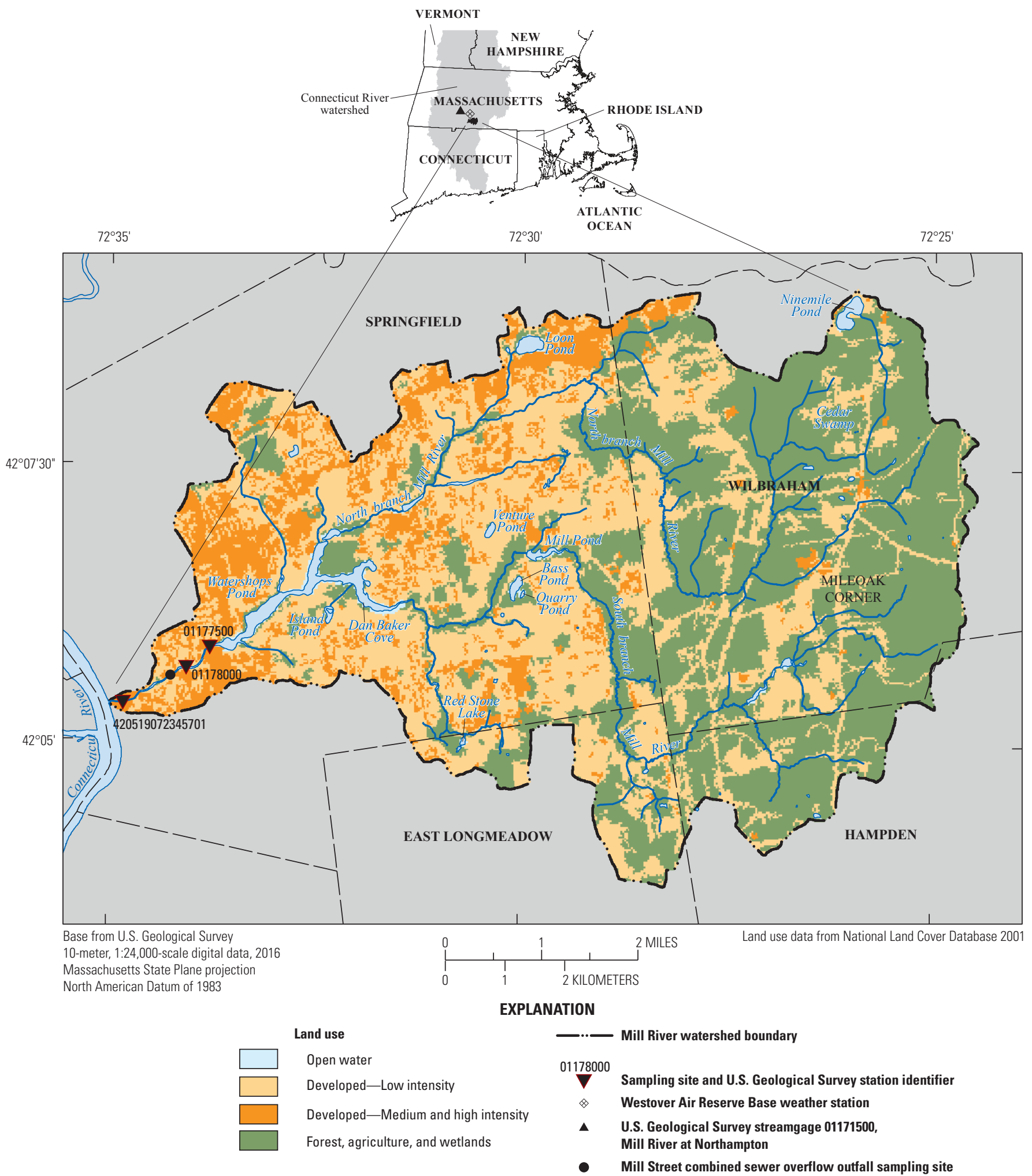

Figure 1. The Mill River watershed in central Massachusetts and the location of the study area, land use, and sample sites on the Mill River, Springfield, Massachusetts. 
$\boldsymbol{A}$

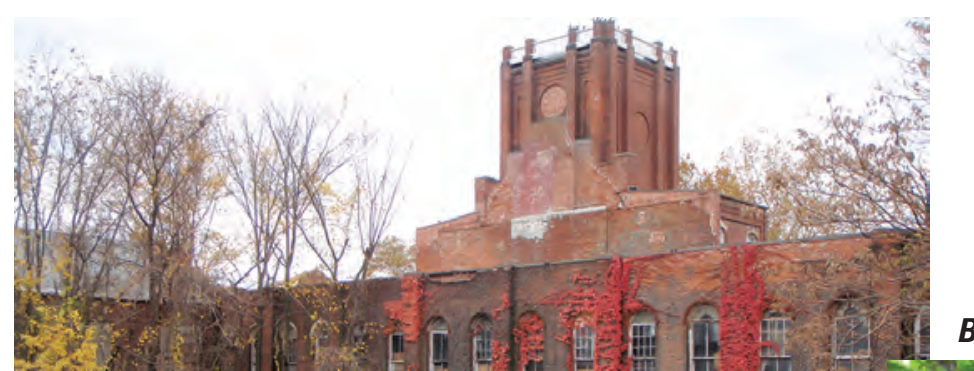

$B$

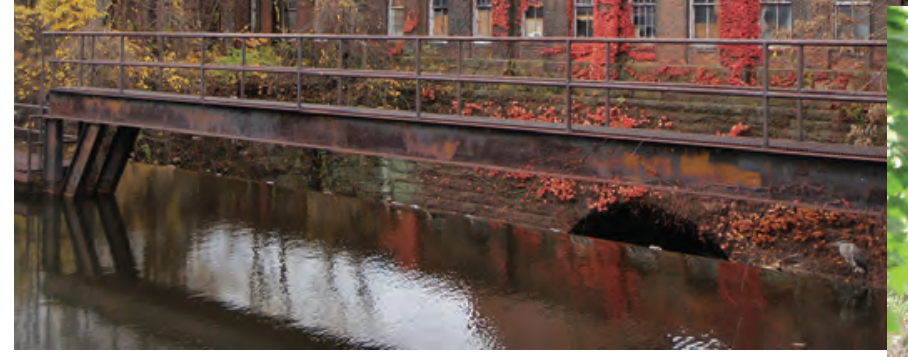

C

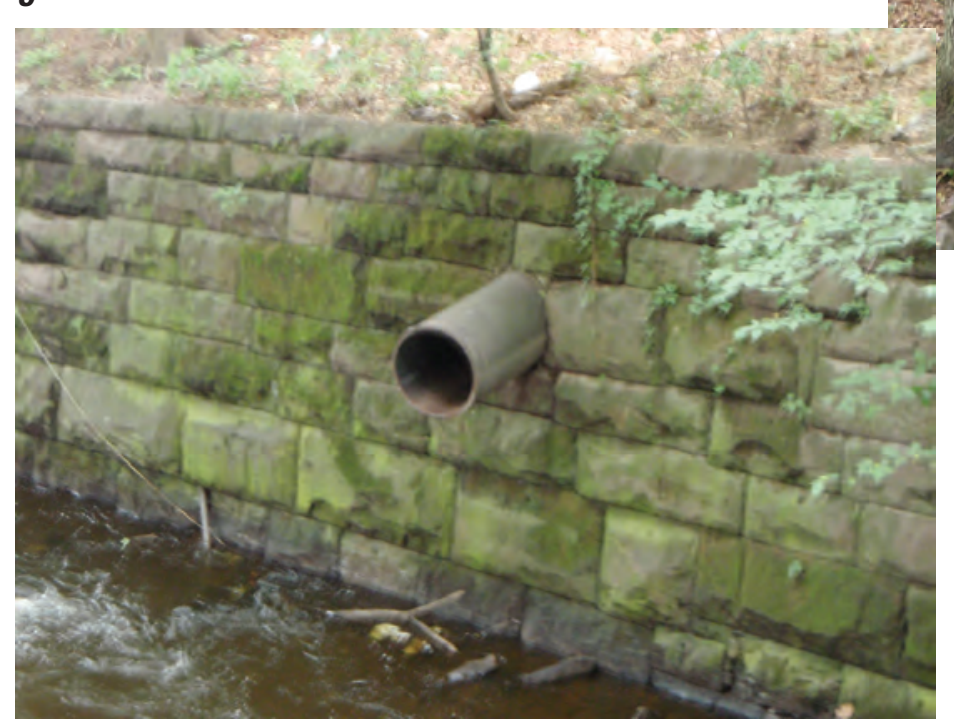

Figure 2. The Mill River in Springfield, Massachusetts. $A$, Watershops mill complex. $B$, Mill River channel above Hancock Street. $C$, A relic drain. Photographs by Andrew J. Massey, U.S. Geological Survey.

and its outfall is to the Connecticut River downstream from the mouth of the Mill River.

The Mill River watershed has been developed for many uses since the founding of Springfield in 1636. Historic farms and old mill sites throughout the upper watershed took advantage of fertile soils, varied terrain, and proximity to the Connecticut River. During the 19th century, the lower river was extensively harnessed through several large mill complexes and was channelized for further control and use of its flow. The steep, rocky channel through Springfield's neighborhoods near the Mill River proved ideal and provided abundant power. Many man-made structures remain and continue to convey water through the Watershops area.

\section{Potential Sources of Contamination in the Mill River Watershed}

Several point and nonpoint sources potentially contribute wastewater contaminants to the Mill River. At the time of this study, there were several CSOs in the densely populated urban area along the Mill River near the confluence with the Connecticut River (Pioneer Valley Planning Commission, 2005a; U.S. Environmental Protection Agency, 2009). A CSO can contribute more pharmaceutical compounds than the associated wastewater treatment plant discharge, even though the total volume of water released by the CSO is much smaller (Phillips and others, 2012). Although CSOs are designed to 
release wastewater under high-flow conditions, during which dilution rates in the receiving stream are high, some contaminants may remain in the receiving stream reach, mixed in with new sediment deposits, and may be remobilized long after the initial CSO release. The fate and persistence of some pharmaceutical compounds in surface waters, groundwater, and aquatic sediments is poorly understood. Some sewage indicator compounds are easily biodegraded or photo-oxidized, but other compounds can persist, particularly in aquatic sediments or along groundwater flow pathways (Fono and others, 2006; Cantwell and others, 2010; Radke and others, 2010; Musolff and others, 2010).

Combined sewer systems (CSSs) collect domestic wastewater for much of the Mill River watershed and convey it to a wastewater treatment plant. However, some CSSs discharge untreated sewage to surface waters during periods of heavy runoff (a CSO event); the overflow occurs when the outdated infrastructure exceeds sanitary-design capacity. CSSs, in which sewage and stormwater flow to a treatment plant through a single pipe, were in use in the area around the lower Mill River during the study. CSOs may convey untreated domestic, commercial, and industrial wastes along with stormwater runoff into receiving waters like the Mill River. Major efforts have been underway since the 1990s to address CSSs by separating stormwater and wastewater systems along the Connecticut River, and future efforts are proposed to address the remaining CSSs (Pioneer Valley Planning Commission, 2005a; Springfield Water and Sewer Commission, 2012). However, from the 1990s through the study period (2010-11), multiple heavy rainfall events per year still resulted in untreated wastewater discharge through CSOs. In 2005, the Pioneer Valley Planning Commission reported a CSO discharge reduction of $3.2 \mathrm{Mgal} / \mathrm{yr}$ to the Mill River (Pioneer Valley Planning Commission, 2005b), and in 2012, the Springfield Water and Sewer Commission reported extensive improvements to sewer infrastructure near the Mill River. These infrastructural improvements, mandated through an administrative consent order issued by the EPA, further reduced Mill River CSO discharge by 98 percent, from an original 1990s-era discharge volume of $61.2 \mathrm{Mgal} / \mathrm{yr}$ to a current volume of $1.2 \mathrm{Mgal} / \mathrm{yr}$ (Springfield Water and Sewer Commission, 2012). CSOs may contribute smaller amounts of fecal coliform and Escherichia coli (E. coli) bacteria to the river system than other nonpoint sources on an annual basis yet, on a daily or weekly basis, be the main source of these and other anthropogenic contaminants to downriver sections of the river.

In more rural areas of the watershed, contaminants can have various nonpoint sources (U.S. Environmental Protection Agency, 2002; Brown and Trombley, 2009). In these rural areas, household wastewater is treated with onsite septic systems. Drainage from these systems, particularly if they are not functioning properly, can contribute contaminants to nearby surface waters (U.S. Environmental Protection Agency, 2014; Del Rosario and others, 2014; Phillips and others, 2015).

Many residential areas in the Mill River watershed are on public sanitary sewer lines, through which sewage is transported to a regional treatment plant outside the watershed; however, aging infrastructure can result in leakage from pipes and seals, contributing to contamination of urban streams (Fono and Sedlak, 2005; Phillips and Chalmers, 2009).

Other nonpoint sources of contaminants and bacteria can also contribute to river water-quality impairment. Runoff from livestock-affected areas, domestic animal wastes from residential areas, application of fertilizer, and groundwater discharge containing poorly treated septic effluent may also contribute nutrients and bacteria to the river system (Kolpin and others, 2002; Barnes and others, 2008; Focazio and others, 2008). Water fowl, especially large flocks of migratory species, which typically stop only briefly at resting areas, may become year-round residents at locations with abundant food, rearing habitat, or supplemental feeding from human activity (fig. 3).

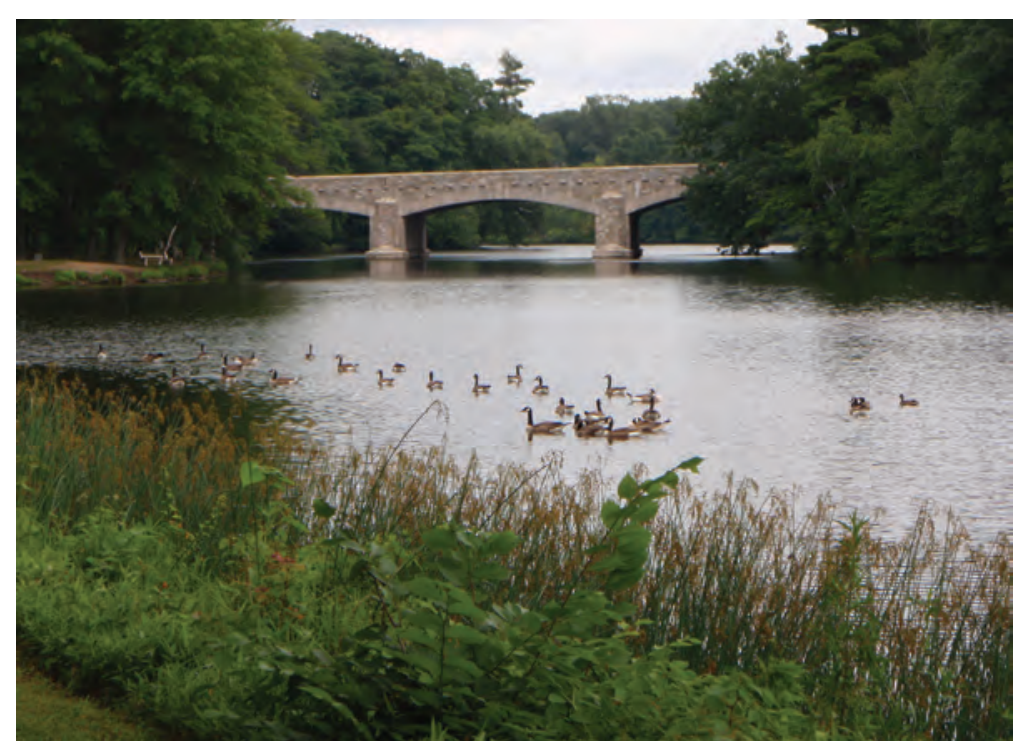

Figure 3. Resident geese at Watershops Pond near Springfield College and Wesson Park, Springfield, Massachusetts. Photograph by Andrew J. Massey, U.S. Geological Survey. 


\section{Site Selection and Sample Collection}

The Pioneer Valley Planning Commission, Connecticut River Joint Commissions, Franklin Regional Council of Governments, University of Massachusetts Water Resources Research Center, and USGS chose a portion of the Mill River below Watershops Pond (fig. 1) to address concerns about water quality in the Mill and Connecticut Rivers. These concerns centered on the densely populated, urbanized lower reaches of Mill River because of the uncertainty associated with contaminant inputs from nonpoint sources under low-flow conditions. Initially, two sample sites were chosen along the river to allow comparisons of water quality between upriver (near the outlet of Watershops Pond, USGS site number 01177500) and downriver (Hancock Street, USGS site number 01178000) sites (fig. 1). Water samples were collected four times, each with an antecedent dry period of at least 3 days, following a monthly schedule from late July 2010 through early November 2010 (fig. 4). In October, a third sample site (USGS site number 420519072345701) was added at the river mouth, just upriver from the confluence with the Connecticut River. Water samples were collected by using trace-level (parts-per-billion) protocols (Wilde and others, 2004). Samples were collected under low-flow conditions to determine whether wastewater contaminants indicative of sewage were present in the Mill River under these conditions, as have been observed for other rivers in New England.

Samples of Mill River water were collected by using various equipment and procedures depending on the conditions at each site, following guidance from the USGS "National Field Manual for the Collection of Water-Quality Data" (U.S. Geological Survey, variously dated). Where access was available and where water depth was sufficient, a US DH-81 wading sampler was used. Where wading was not possible but water depth was sufficient and access was appropriate, a tethered weighted-bottle sampler equipped with a 1-liter sample bottle of baked amber glass was used. At certain sites, where water depths were too shallow to permit sampling with a US DH-81 or weighted-bottle sampler, grab samples were collected in sterile plastic flasks or 3-liter Teflon bottles. For grab samples, water was collected by multiple grabs from several verticals to approximate equal-width-increment (EWI) procedures (Wilde and others, 2004). This adaptation is required for low-water conditions, where flow velocities are usually inadequate to meet the strict EWI criteria. All samples were immediately put on ice after collection and transported to the Massachusetts Department of Environmental Protection (MassDEP) Senator William X. Wall Experiment Station (WES) laboratory in Chelmsford, Massachusetts, or the USGS laboratory in Northborough, Massachusetts, on the same day that they were collected. Samples for pharmaceutical analysis were shipped chilled overnight to the USGS National Water Quality Laboratory (NWQL) in Lakewood, Colorado.

A grab sample of raw sewage was collected from the Springfield sewer at Mill Street, near the Mill Street CSO (fig. 1), on March 17, 2011. The sample was diluted with deionized water $(50: 1)$ prior to analysis. This raw sewage sample was analyzed for the same wastewater contaminants as the samples from the Mill River. Two samples were also

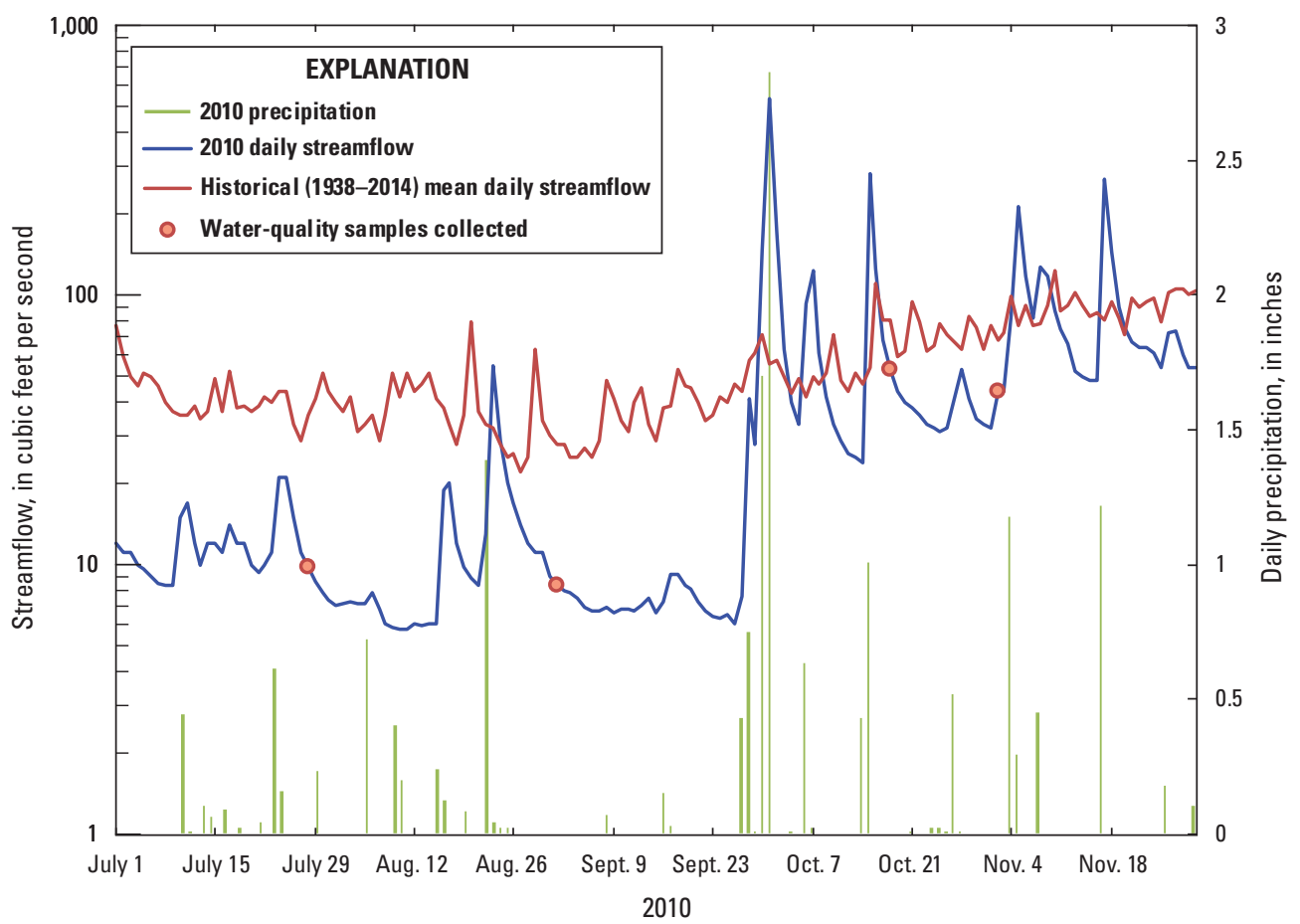

Figure 4. Precipitation near the Mill River recorded at Westover Air Reserve Base, Massachusetts, sample dates for the period from July 1, 2010, through November 30, 2010, daily streamflow at the nearby Mill River in Northampton, Massachusetts (USGS streamgage 01171500), during this period, and historical mean daily streamflow for the period November 1938 to September 2014. 
collected from the Mill River on March 17, 2011. One sample was collected from the site upriver and one from the site downriver of the Mill Street CSO site (fig.1). The Springfield Water and Sewer Commission reported that the CSO had been triggered by a rain/snowmelt event on March 16, 2011, but had ended and was not flowing into the Mill River at the time of sampling (0800 March 17, 2011). The raw sewage sample was collected for comparison of its results with those of the samples collected from the Mill River, to determine whether the pharmaceutical compounds and fluorescence whitening agents (FWAs) that were assessed in the Mill River samples were present in raw sewage, and to determine if constituents from the CSO release were detectable downstream from the outfall.

\section{Analysis for Sewage Constituents}

Field parameters were measured on each day when water samples were collected for laboratory analyses of wastewater constituents. Water samples were collected and analyzed for several indicators of anthropogenic wastewater contaminants, including pharmaceutical compounds, fecal coliform bacteria, and FWAs. Fecal coliform bacteria were enumerated and analyzed for host-specific genetic markers to determine whether they were of human or nonhuman origin. For quality assurance, water samples were split and analyzed independently for E. coli bacteria by USGS and by WES.

\section{Pharmaceutical Compounds}

Water samples were collected and analyzed for pharmaceutical compounds by using methods developed by USGS (Furlong and others, 2008). Mill River water samples were filtered through a 0.47 -micrometer glass-fiber filter on a freestanding aluminum filter plate placed inside an isolation chamber. A Teflon diaphragm pump with C-Flex tubing was used to force the raw-water sample through the filter into 1-liter baked amber-glass sample bottles. Samples were analyzed by NWQL for 14 pharmaceutical compounds and metabolites (table 1) by solid-phase extraction onto chemically modified styrene-divinylbenzene resin, followed by high-performance liquid chromatography/mass spectrometry (Furlong and others, 2008). In this report, analytical results are presented if the concentration was greater than the NWQL reporting level (RL) or as detected if they were observed at concentrations less than the RL. The RL is defined as two times the long-term analytical method detection limit observed by the laboratory (Furlong and others, 2008). Adjustments to RLs are commonly made by the NWQL and are based on statistical quantification of the analytical-method performance. An explanation of how RLs are determined is available elsewhere (Childress and others, 1999).
Table 1. Human-health pharmaceutical compounds measured in water from the Mill River at three sites from Watershops Pond to the mouth above the Connecticut River, Springfield, Massachusetts, 2010-11.

\begin{tabular}{lll}
\hline \multicolumn{1}{c}{ Compound name } & $\begin{array}{c}\text { Chemical } \\
\text { Abstracts } \\
\text { Service } \\
\text { Registry } \\
\text { Number } \\
\text { (CASRN) }\end{array}$ & \multicolumn{1}{c}{ Primary use } \\
\hline 1,7-dimethylxanthine & $611-59-6$ & Caffeine metabolite \\
Acetaminophen & $103-90-2$ & Antipyretic \\
Albuterol (Salbutamol) & $18559-94-9$ & Antiasthmatic \\
Caffeine & $58-08-2$ & Stimulant \\
Carbamazepine & $298-46-4$ & Antiepileptic \\
Codeine & $76-57-3$ & Analgesic \\
Cotinine & $486-56-6$ & Nicotine metabolite \\
Dehydronifedipine & $67035-22-7$ & Antianginal \\
Diltiazem & $42399-41-7$ & Antihypertensive \\
Diphenhydramine & $147-24-0$ & Antihistamine \\
Sulfamethoxazole & $723-46-6$ & Antibiotic \\
Thiabendazole & $148-79-8$ & Antifungal, antihelmintic \\
Trimethoprim & $738-70-5$ & Antibiotic \\
Warfarin & $81-81-2$ & Anticoagulant \\
\hline
\end{tabular}

${ }^{1}$ This report contains CAS Registry Numbers ${ }^{\circledR}$, which is a registered trademark of the American Chemical Society. CAS recommends the verification of the CASRNs through CAS Client Services ${ }^{\mathrm{SM}}$.

\section{Field Parameters}

Measurements of field parameters (temperature, specific conductance, $\mathrm{pH}$, and dissolved oxygen) were made with a multiparameter water-quality-monitoring instrument that was calibrated before each use on the day of sampling in accordance with manufacturer's instructions and USGS protocols (Wilde and others, 2004). During deployment at all sample sites, the instrument was lowered into the thalweg to a depth of about 0.3 meter below the water surface (table 2 ).

\section{Fecal Coliform Bacteria and Host-Specific Genetic Markers}

Three types of bacteria were assessed for potential human sewage origin in this study: Bacteroidetes, Enterococcus, and E. coli. All three are common bacteria associated with fecal contamination from humans and warm-blooded animals; Enterococcus and E. coli are also indicator organisms that are widely used in testing and regulating water quality. E. coli and enterococci bacteria were enumerated in Mill River samples by using modified mTEC agar and membrane filtration 
Table 2. Field parameters measured in river water and bacteria results from samples collected intermittently at four sites at the Mill River, Springfield, Massachusetts, from Watershops Pond to the mouth above the Connecticut River, July 2010 through March 2011.

[Escherichia coli (E. coli) samples were independently analyzed by U.S. Geological Survey (USGS) and Massachusetts Department of Environmental Protection Wall Experiment Station (WES) personnel. Results for E. coli replicate samples are in parentheses. ${ }^{\circ} \mathrm{C}$, degree Celsius; $\mu \mathrm{S} / \mathrm{cm}$ at $25{ }^{\circ} \mathrm{C}$, microsiemens per centimeter at $25^{\circ} \mathrm{C} ; \mathrm{mg} / \mathrm{L}$, milligram per liter; $\mathrm{CFU} / 100 \mathrm{~mL}$, colony forming unit per 100 milliliters; --, not sampled; <, less than; >, greater than]

\begin{tabular}{|c|c|c|c|c|c|c|c|}
\hline Sample site & $\begin{array}{l}\text { Temperature } \\
\quad\left({ }^{\circ} \mathrm{C}\right)\end{array}$ & $\begin{array}{c}\text { Specific } \\
\text { conductance } \\
\text { ( } \mu \mathrm{S} / \mathrm{cm} \text { at } 25 \\
\left.{ }^{\circ} \mathrm{C}\right) \\
\end{array}$ & $\begin{array}{c}\text { pH } \\
\text { (standard } \\
\text { units) }\end{array}$ & $\begin{array}{c}\text { Dissolved } \\
\text { oxygen } \\
\text { (mg/L) }\end{array}$ & $\begin{array}{c}\text { E. coli } \\
\text { (USGS) } \\
\text { (CFU/100 } \\
\text { mL) }\end{array}$ & $\begin{array}{c}\text { E. coli } \\
\text { (WES) } \\
\text { (CFU/100 mL) }\end{array}$ & $\begin{array}{l}\text { Enterococci } \\
\text { (WES) } \\
\text { (CFU/100 mL) }\end{array}$ \\
\hline \multicolumn{8}{|c|}{ July 28, 2010} \\
\hline Mill River at Watershops Pond- 01177500 & 25.4 & 321 & 8.83 & 10.3 & -- & 19 & 14 \\
\hline Mill River at Hancock Street—01178000 & 24.9 & 326 & 8.31 & 6.93 & 2,500 & $\begin{array}{c}2,200 \\
(1,800)\end{array}$ & 1700 \\
\hline Mill River at Mouth - 420519072345701 & -- & -- & -- & -- & -- & -- & -- \\
\hline \multicolumn{8}{|c|}{ September 1, 2010} \\
\hline Mill River at Watershops Pond -01177500 & 24.7 & 307 & 9.69 & 14.2 & $<10$ & $<5$ & 14 \\
\hline Mill River at Hancock Street—01178000 & 25.4 & 307 & 9.46 & 6.36 & 1,825 & $\begin{array}{l}1,800 \\
(2,100)\end{array}$ & 1200 \\
\hline Mill River at Mouth— 420519072345701 & -- & -- & -- & -- & -- & -- & -- \\
\hline \multicolumn{8}{|c|}{ October 18, 2010} \\
\hline Mill River at Watershops Pond- 01177500 & 12.7 & 263 & 6.81 & 6.36 & 23 & 10 & 3 \\
\hline Mill River at Hancock Street—01178000 & 12.6 & 266 & 7.28 & 9.24 & 157 & 120 & 210 \\
\hline Mill River at Mouth— 420519072345701 & 12.4 & 267 & 7.66 & 9.82 & 230 & 210 & 260 \\
\hline \multicolumn{8}{|c|}{ November 2, 2010} \\
\hline Mill River at Watershops Pond—01177500 & 10.7 & 284 & 7.17 & 7.22 & 12 & 10 & 3 \\
\hline Mill River at Hancock Street—01178000 & 10.5 & 287 & 7.52 & 10.6 & 78 & $\begin{array}{c}57 \\
(71)\end{array}$ & 78 \\
\hline Mill River at Mouth—420519072345701 & 10.3 & 289 & 5.63 & 11.3 & 180 & 150 & 110 \\
\hline \multicolumn{8}{|c|}{ March 17, 2011} \\
\hline Mill River at Watershops Pond—01177500 & -- & -- & -- & -- & -- & -- & -- \\
\hline Mill River at Hancock Street—01178000 & 3.52 & 224 & 6.85 & 13.53 & 160 & 120 & 190 \\
\hline Mill River at Mouth—420519072345701 & 3.59 & 226 & 7.11 & 13.64 & $\begin{array}{c}157 \\
(113)\end{array}$ & $\begin{array}{c}120 \\
(100)\end{array}$ & 180 \\
\hline $\begin{array}{l}\text { Sewer at Mill River combined sewer over- } \\
\text { flow_-420536072340901 }\end{array}$ & -- & -- & -- & -- & 47,000 & $>20,000$ & $>1,300$ \\
\hline
\end{tabular}

according to EPA Methods 1603 and 1600, respectively (U.S. Environmental Protection Agency, 2000) in the WES laboratory. Quality-control samples (that is, sterile blanks, duplicates, and the raw sewage sample) were tested with each batch of samples analyzed by WES laboratory. In addition, the USGS analyzed replicate samples for enumeration of E. coli by following Myers and others (2007).

Analysis of human-host-specific genetic markers for Bacteroidetes organisms can be used to infer human sources of fecal coliform bacteria (Bernhard and Field, 2000a and 2000b). Additionally, techniques and quality-assurance procedures have been developed by the MassDEP that allow identification of human-sewage-derived fecal bacteria in water samples (Tang and others, 2006).

After enumeration, the enterococci samples were preserved for genetic speciation by two conventional polymerase chain reaction (PCR) assays. The esp gene assay is used to detect a genetic marker specific to human sewage (that is, a putative virulence factor, the esp gene coding for an exocellular surface protein) in Enterococcus faecium, an indicator of fecal contamination (Scott and others, 2005). In this assay, water samples were first analyzed for culturable enterococci by membrane filtration on $\mathrm{mEI}$ agar plates according to EPA Method 1600. The colonies that grew on the mEI plates were then harvested as a group, and associated DNA was 
extracted. The extracted DNA was then analyzed for the presence of the esp gene according to the procedure of Scott and others (2005).

The second PCR assay used fecal Bacteroidetes for the detection of human-specific ribosomal DNA markers (Bernhard and Field, 2000a). Bacteroidetes is a group of anaerobic bacteria present in high concentrations in human and other animal feces. For this assay, water samples were filtered through polycarbonate filters (GE Osmonics, Inc., Minnetonka, Minnesota). DNA was extracted from the polycarbonate filters and tested for the presence of fecal Bacteroidetes by using a group-specific primer set to detect the human-specific genetic marker sequence Bacteriodetes-Prevotella (GB32) (Bernhard and Field, 2000a). The samples that contained the fecal Bacteroidetes group were further tested with human-specific primers (Bernhard and Field, 2000a) for the two genetic markers, HF134 and HF183, by methods described in Duerring and others (2010).

\section{Fluorescent Whitening Agents}

Fluorescent whitening agents, or optical brighteners (OBs), are commonly used additives to laundry detergents, fabrics, paper products, and other manufactured goods and therefore are frequently found in domestic sewage and can be used as indicators of wastewater in environmental samples. Fluorescent whitening agents (including FWA-1, FWA-2, FWA-4, OB-1 and OB-2) were quantitated in water samples in the WES laboratory by using a method of solid-phase extraction and high-performance liquid chromatography (Duerring and others, 2010), which is a procedure based on Poiger and others (1996).

\section{Quality-Assurance and Quality-Control Procedures}

For quality assurance, quality-control (QC) samples were collected in the field and produced in the laboratory to assess sampling and analytical procedures. QC samples helped verify analytical results and consisted of blank samples, replicate samples, and spike samples. Blank samples were collected to check for potential contamination in the process of sampling and laboratory analysis. The replicate sample was used to check precision of laboratory analyses, and the spike was used to assess recovery and analytical accuracy. Field blanks were collected in the same manner and setting as the environmental samples, except that deionized water was used in place of the river water.

Multiple QC procedures and methods were performed before and during the analysis of environmental samples and blank-water blind samples by the WES laboratory. During each round of sampling, 12 total samples were tested: 8 QC samples and 4 environmental samples, or a ratio of 2:1 QC to environmental. All QC samples were analyzed "blind" so the laboratory did not make assumptions about the quality of the water or adjust the analytical method in the laboratory. For each of the four sample sites, WES analyzed 3 samples: 1 environmental sample of Mill River water, 1 trip blank, and 1 replicate or spike. Spikes and replicates were randomly assigned by the USGS and kept blind from WES staff. As a result, WES did not know the difference among samples prior to analysis to ensure every sample was handled in the same way.

Replicate samples are additional samples collected in the field and intended to be identical in composition to the environmental samples. Replicate samples provide a measure of precision that accounts for variability in sample collection and processing (filtering), and for possible effects such as in-bottle compound degradation prior to laboratory analysis (Smith, 2008).

An additional replicate sample was collected to produce the spike sample with the same matrix as a typical Mill River water sample. At the laboratory, the sample to be spiked was subsequently fortified at 0.25 microgram per liter $(\mu \mathrm{g} / \mathrm{L})$ for all pharmaceutical compounds analyzed for this study and for two additional surrogate compounds. The percent recovery for each target compound added to the environmental sample is used to determine bias and variability arising from (1) the degradation of target compounds during shipment to and holding by the laboratory, (2) the analytical method, and (3) interferences that mask or enhance determinations of the target compounds in the environmental sample as a result of matrix effects (Smith, 2008).

In addition to the types of QC samples collected during this project, the NWQL routinely analyzes other types of QC samples, including laboratory-reagent blanks, interferencecheck solutions, laboratory control samples, standard-reference materials, laboratory-reagent spike samples, and laboratory duplicate samples to test and track method performance (Garbarino and others, 2006; Furlong and others, 2008). The NWQL also adds two surrogate compounds (carbamazepine-d10 and ethyl nicotinate-d4) to all samples for routine determinations of percent recovery. Surrogate compounds are expected to react similarly to the targeted environmental compounds in the laboratory. Because these compounds are not normally found in the environment, the recovery of the surrogate compounds can be used to qualify the performance of the analysis (Smith, 2008).

\section{Results for Field Parameters and Wastewater Constituents}

The following sections describe the results of the analyses of field parameters, pharmaceutical compounds, fecal coliform bacteria, host-specific genetic markers in fecal coliform bacteria, and whitening agents. This section also describes the results of an analysis of the QC samples. 


\section{Field Parameters}

Analyses of field parameters (temperature, specific conductance, $\mathrm{pH}$, and dissolved oxygen) in the river water provided information on basic water-quality conditions at the time of sample collection. Temperatures ranged from a high of 25.4 degrees Celsius $\left({ }^{\circ} \mathrm{C}\right)$ during July and September to a low of $3.5^{\circ} \mathrm{C}$ in March and were similar among sites on each sample date (table 2). Water temperatures were in the mid-20s $\left({ }^{\circ} \mathrm{C}\right)$ during the summer in the narrow river channel, where shaded conditions dominated because of the dense tree canopy and locally steep valley walls.

Specific conductance measurements were within a narrow range from 263 to 326 microsiemens per centimeter $(\mu \mathrm{S} / \mathrm{cm})$ from July through November in 2010 (table 2). Specific conductance was consistent among sites on each sample date. During March 2011, specific conductance was somewhat lower than during the summer and fall of 2010, and measurements were also similar between sites.

The $\mathrm{pH}$ measurements at Watershops Pond impoundment were relatively high during the summer months over the course of the study and ranged from a high of $9.69 \mathrm{pH}$ units on September 1, 2010, to a low of $6.81 \mathrm{pH}$ units on October 18, 2010 (table 2). Measurements of $\mathrm{pH}$ were near neutral at the Hancock Street site as compared with measurements from the upriver Watershops Pond site.

Dissolved oxygen was elevated in Watershops Pond during the summer months of July and September 2010 and coincided with high $\mathrm{pH}$ measurements (table 2). Elevated dissolved oxygen in Watershops Pond was likely the result of photosynthesis by green algae (fig. 5). Sunlight can cause rapid reproduction of green algae in waters with abundant nutrient loads. In turn, photosynthesis by the algae may cause dissolved oxygen concentrations to increase during daylight hours.

\section{Pharmaceutical Compounds}

None of the pharmaceutical compounds were detected at concentrations greater than their analytical reporting levels during the July through November sampling. Detections of caffeine; 1,7-dimethylxanthine, a metabolite of caffeine; carbamazepine, an antiepileptic; and cotinine, a metabolite of nicotine, were found at sub-part-per-billion concentrations (table 3), but they could not be reliably quantified because these concentrations were below their RLs.

The samples collected in March 2011 included two environmental samples and the grab sample of raw sewage from the sewer main near the Mill Street CSO along the lower reach of the Mill River. Four pharmaceutical compounds were detected in the diluted (50:1) raw sewage (table 3). After the dilution factor was applied, the estimated undiluted concentrations were caffeine at $31 \mu \mathrm{g} / \mathrm{L}$, acetaminophen at $10 \mu \mathrm{g} / \mathrm{L}$, and the caffeine metabolite 1,7-dimethylxanthine at $31 \mu \mathrm{g} / \mathrm{L}$. The antibiotic trimethoprim was detected at a low estimated

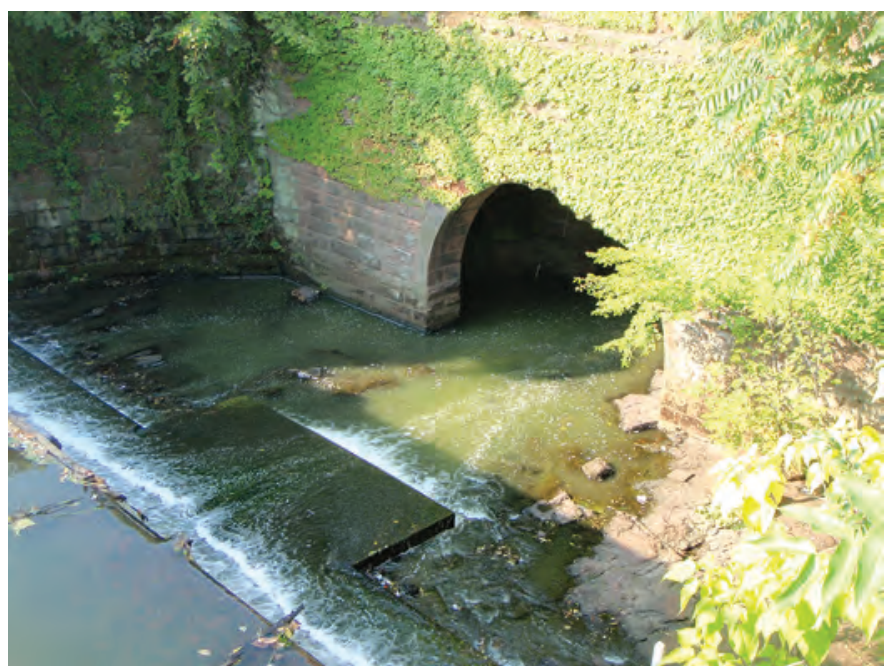

Figure 5. Green algae in Mill River water spilling from Watershops Pond impoundment under the mill at Watershops Pond, Springfield, Massachusetts, September 1, 2010. Photograph by Andrew J. Massey, U.S. Geological Survey.

concentration, well below the RL in the diluted sewage (table 3). No pharmaceutical compounds were detected in the environmental samples collected at Mill River sites upriver (Hancock Street) and downriver (at the mouth) of the CSO on March 17th except caffeine, which was detected in samples from both locations at estimated concentrations below the RL. Therefore, any potential residual contamination from the CSO release on March 16th had probably flushed through the lower reach to the Connecticut River, or was at such a diluted concentration that it was not detectable (table 3).

\section{Fecal Coliform Bacteria and Host-Specific Genetic Markers}

Concentrations of the fecal indicator bacteria $E$. coli were present in Mill River water at each site sampled and at all sample times (table 2). Concentrations of E. coli generally increased along the course of the river from Watershops Pond to the mouth and were greatest in samples collected during the summer (fig. 6). The highest $E$. coli concentration, 2,500 colony-forming units per 100 milliliters (CFU/100 mL), was measured in late July 2010 in samples of water collected at the Hancock Street site. E. coli concentrations in late July and early September were above the Massachusetts criterion for a single sample collected at a site far from bathing beaches (235 CFU/100 mL maximum). E. coli concentrations were lower during cooler months, but all samples of the river contained E. coli.

The results for enterococci bacteria were similar to the results of the E. coli analysis. All samples contained enterococci bacteria, and bacterial concentrations generally increased 


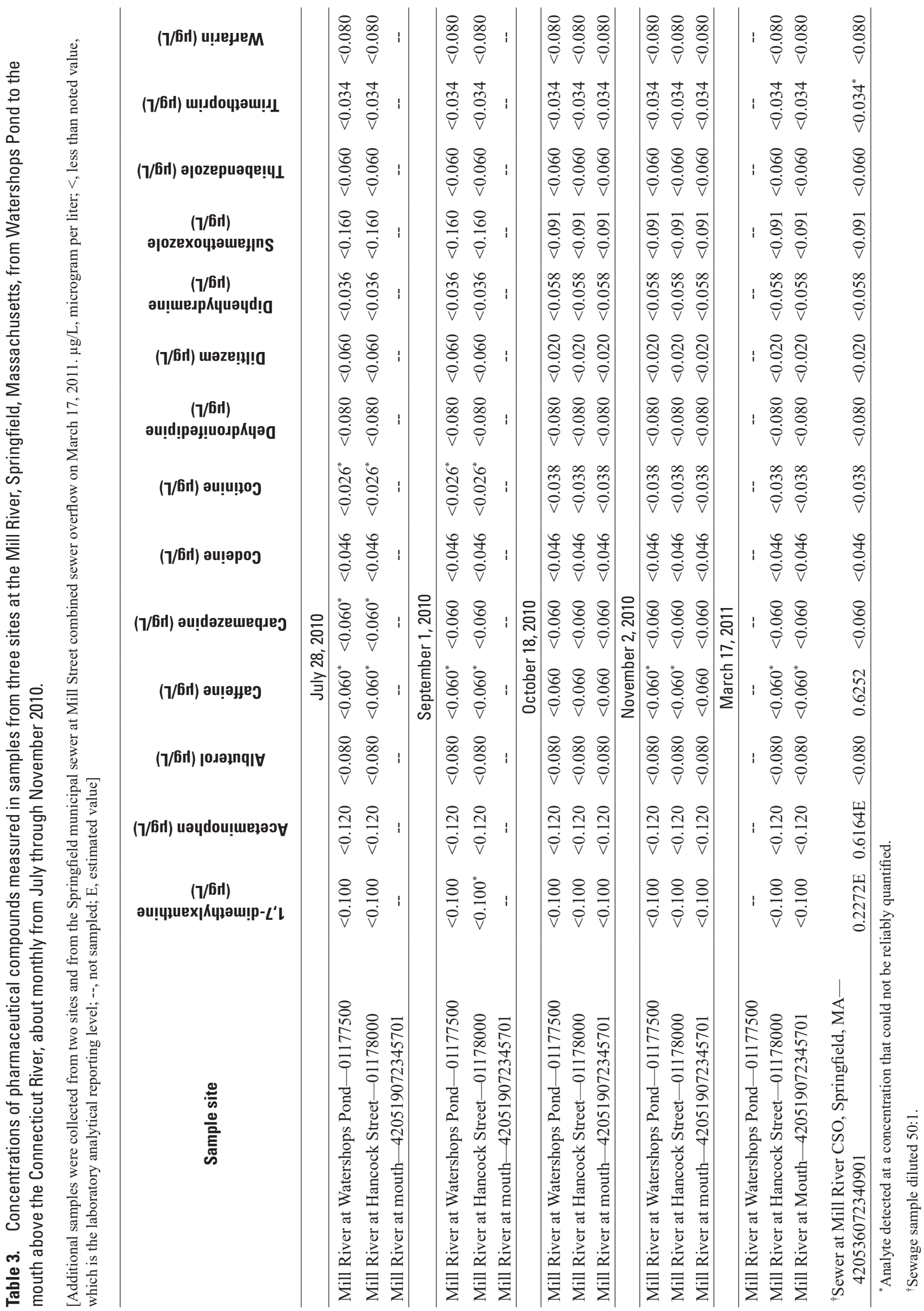




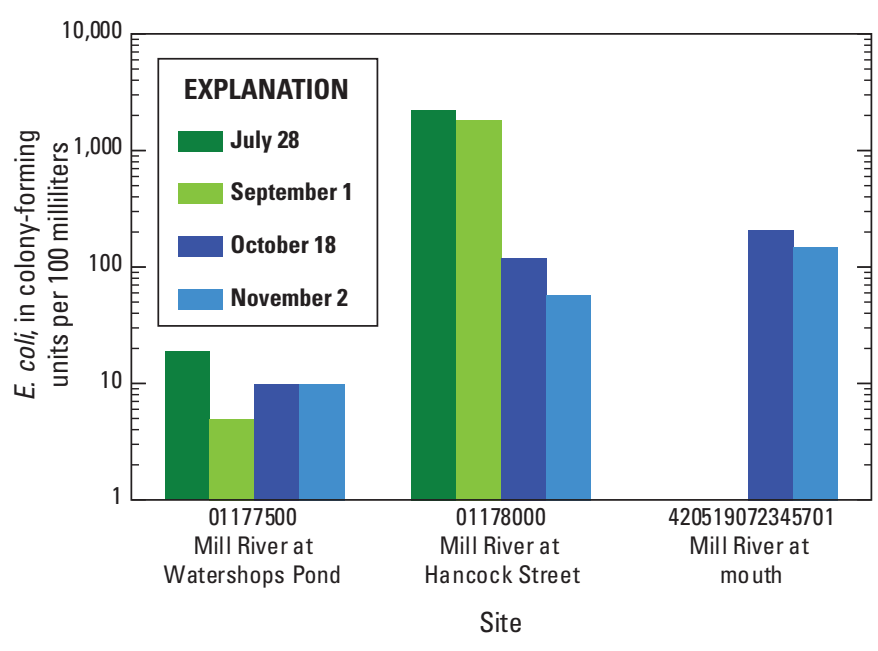

Figure 6. Escherichia coli (E. coli) concentrations measured in samples of Mill River water, Springfield, Massachusetts, collected from three sites and at four times during summer and fall 2010.

from Watershops Pond to the mouth (table 2) (fig. 7). One Mill River sample (collected at Watershops Pond on October $18,2010)$ tested positive for the presence of the esp gene. Only three colonies were counted on the culture plate from this sample, so there was little material for the DNA analysis. By contrast, the cultures from the two downriver sites grew over 200 colonies of enterococci, and the genetic material collected from these cultures tested negative for the esp gene. The diluted raw sewage sample also grew robust cultures of enterococci, and this DNA material tested positive for the esp gene (table 2).

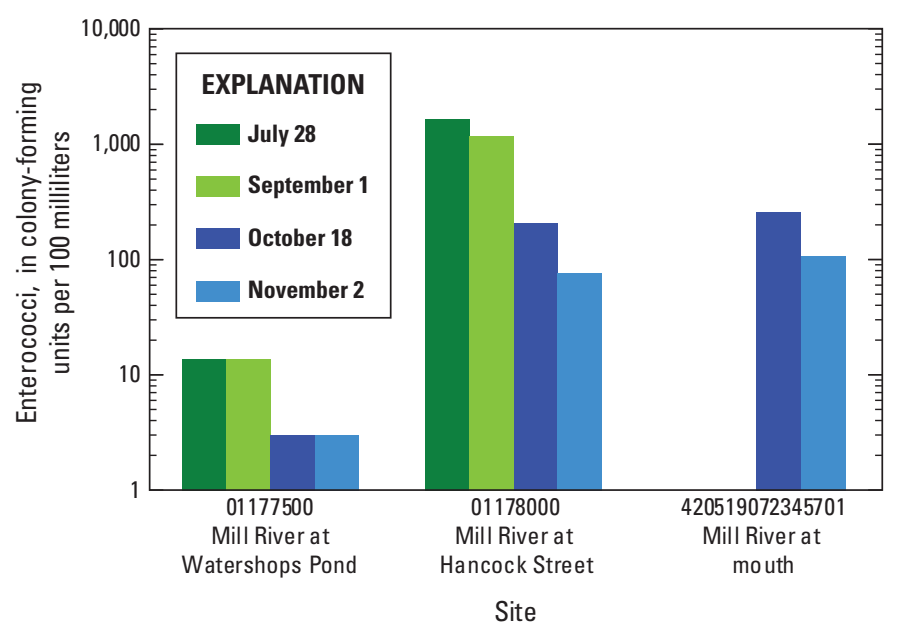

Figure 7. Enterococci concentrations measured in samples of Mill River water, Springfield, Massachusetts, collected from three sites and at four times during summer and fall 2010.
In July, the Bacteroidetes group marker (GB32) was absent from water samples. In September, GB32 was present in both samples, but the human-specific rDNA markers were absent. In October, GB32 was absent from the upriver site but present in water collected from the lower two sample sites. Further analysis for the human-specific markers determined a presence in only the downriver site (Mill River at mouth). November results were similar to October results except that the group marker was also present in the sample collected from the upriver location (Mill River at Watershops Pond). Samples from the Watershops Pond and Hancock Street sites tested negative in 2010 for two Bacteroidetes human-specific genetic markers, HF134 and HF183, but the sample from the site near the river mouth tested positive for both markers in October and November (table 4). Samples from all three sites tested positive in March 2011 for both genetic markers, HF134 and HF183.

\section{Fluorescent Whitening Agents}

The water sample collected at the upriver Watershops Pond site on July 28,2010 , contained $2.75 \mu \mathrm{g} / \mathrm{L}$ of FWA-1 (table 4). FWA-1 was also detected in a sample collected on the same day at the downriver Hancock Street site at a concentration below the minimum reporting level (table 4). FWA-1 and FWA-2 were detected in samples collected in October 2010, but the presence of these compounds in the Mill River is uncertain because they were also detected in the corresponding blanks (table 4). Concentration of fluorescent whitening agent- 1 in the diluted sewage sample was 90,000 times greater than the median concentration in the Mill River samples.

\section{Quality Assurance and Quality Control}

No pharmaceutical compounds were detected in the blank samples (table 5), indicating that samples were not contaminated during sampling or laboratory analysis. There were no measurable differences in concentrations of any compounds between the replicate sample and its corresponding environmental sample (table 5). Caffeine and cotinine were detected in both the river-water sample and its QC replicate, but the concentrations were too small to be reliably quantified (1,7-dimethylxanthine was also detected in the environmental sample at an estimated concentration 3.6 times lower than the RL).

Percent recoveries in the spike sample ranged from 1.8 for sulfamethoxazole to 82.7 for dehydronifedipine (table 5). The percent recovery of carbamazepine-d10 in quality-assurance (QA) samples ranged from 43.9 to 113.3 , whereas the percent recovery of ethyl nicotinate-d4 in QA samples ranged from 75.2 to 103.9 (table 5). The fact that the percent recoveries of the two added surrogate pharmaceutical compounds were consistently substantially higher in blank water than in river water indicates the likelihood of matrix effects masking or degrading pharmaceutical compounds in river water. 


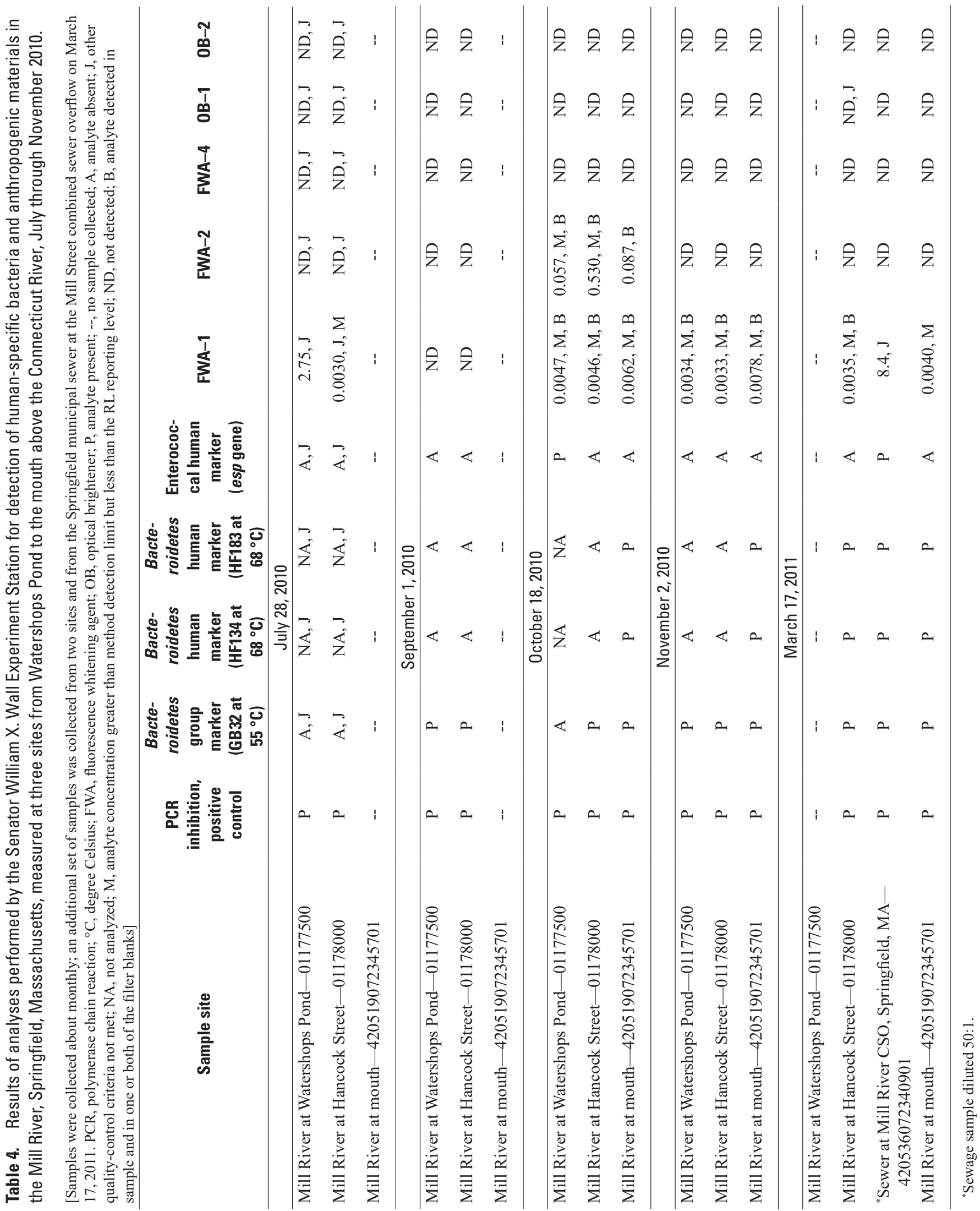




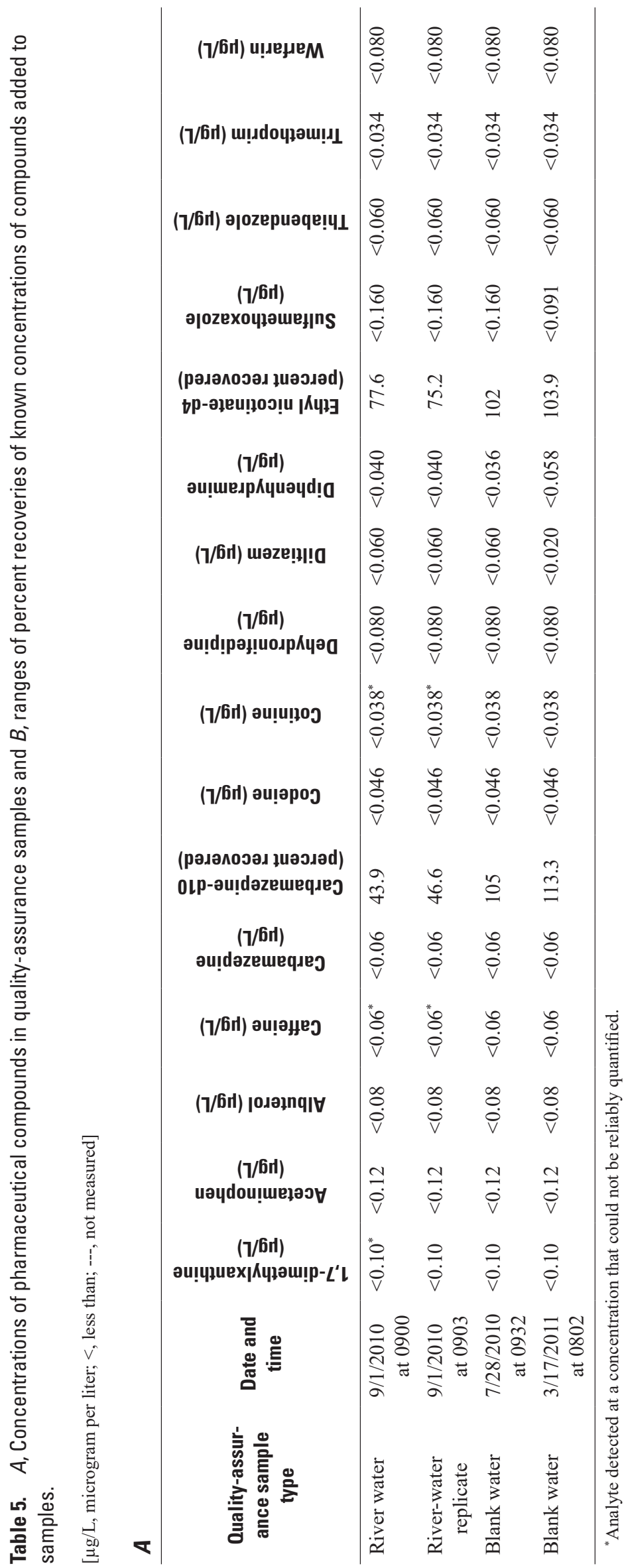

\begin{tabular}{|c|c|}
\hline и!ленем м & $\hat{a}$ \\
\hline ш!цdоцрәш!ц & กุa \\
\hline әооzерuәqе!чц & $\ddot{i}$ \\
\hline әроzехоцџәшең|ns & $\stackrel{\infty}{-}$ \\
\hline 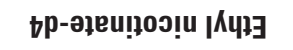 & 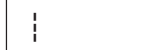 \\
\hline әи!шелрАциәуд! & $\begin{array}{l}\dot{q} \\
\dot{q}\end{array}$ \\
\hline แəzе!!!!0 & $\stackrel{i}{m}$ \\
\hline әu!d!рәң!иолрКчәа & $\underset{i}{i}$ \\
\hline әu!u!ฺo & $\begin{array}{l}m \\
3 \\
6\end{array}$ \\
\hline әи!әроэ & $\vec{\infty}$ \\
\hline оцр-әu!dәzешеqлеэ & 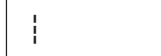 \\
\hline әu!dәzешеqлеэ & $\stackrel{n}{q}$ \\
\hline әu!әџеग & 苜 \\
\hline 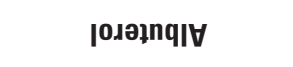 & $\ddot{\dot{\infty}}$ \\
\hline uәцdou!̣щеџәэ૪ & $\stackrel{0}{\circ}$ \\
\hline 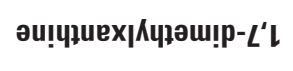 & $\stackrel{0}{\dot{0}}$ \\
\hline 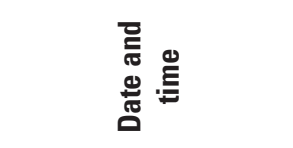 & 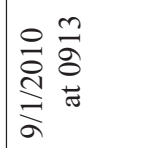 \\
\hline 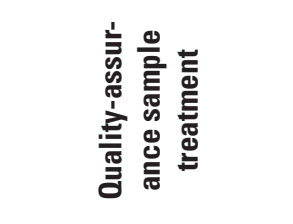 & 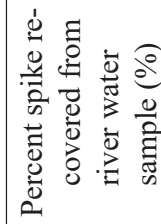 \\
\hline
\end{tabular}


The variability in percent recovery observed among the 14 compounds analyzed in river water likely results from samplespecific matrix effects as well as losses during sample preparation and handling. The ranges of recoveries reported here are comparable to previously published observations for surfacewater samples (Furlong and others, 2008).

\section{Discussion of Wastewater Constituents in the Mill River}

The concentration data for fecal indicator bacteria and pharmaceutical compounds were considered along with other data collected for this study, including the concentrations of FWA and human-specific bacterial genetic markers, to provide multiple lines of evidence with which to assess sewage presence in the Mill River during the low-flow study period. The use of multiple indicators of anthropogenic contamination is important in reliably assessing the potential presence of sewage in the environment because each method has limitations associated with detection limits and RLs. As the contaminant signal of each compound becomes more dilute, analytical methods become less effective at detecting the presence of these compounds at low concentrations.

Water samples for July and September were collected under low-flow conditions compared to historical average flows for a small nearby tributary in the Springfield area (fig. 4). When samples were collected during October and November, flows were estimated to be about five times higher than during the summer months based on the nearby Mill River streamgage in Northampton, Massachusetts, but even these flows were less than the historical averages for the fall period. If any wastewater constituent concentrations were most easily detected under low-flow conditions, then the likelihood of detection was relatively high in samples collected for this study in 2010 .

None of the low-flow samples had concentrations of wastewater constituents above the laboratory RLs, and therefore the constituents were either not present or present at low concentrations. The absence of these compounds at reportable concentrations does not rule out their presence at trace levels. Recent advances in analytical methods have allowed quantification of pharmaceutical compounds at nanogram-per-liter concentrations, whereas the RLs in this study were quantified at tenths to hundredths of a microgram per liter. For example, Benotti and others (2009) reported concentrations of pharmaceutical compounds at nanogram-per-liter concentrations in drinking water. There may be no risk to human health from contaminants at low concentrations, but the effects of chronic exposure to a suite of these compounds is not well understood (Kumar and others, 2010).

Certain indicator compounds were detected at concentrations below the RLs, suggesting that trace amounts of sewage were present. For example, the water sample collected at the upriver Watershops Pond site on July 28, 2010, contained
$2.75 \mu \mathrm{g} / \mathrm{L}$ of FWA-1, and the detection of caffeine below the RL points towards the possibility of sewage contamination at trace-level concentrations (tables 3, 4, and 5). On the same day, caffeine and FWA-1 were also detected at concentrations below the RL at the downriver Hancock Street site. In September, similar results were observed, indicating possible sewage contamination at low levels at both sites and the presence of the Bacteroidetes group marker and detection of caffeine at concentrations below the RL.

In this study, the indicators included testing for the presence of E. coli and enterococci bacteria, two Bacteroidetes human-specific genetic markers (HF134 and HF183), the human-specific genetic marker Enterococcus faecium (esp), a suite of FWAs (FWA-1, FWA-2, and FWA-4), and optical brighteners (OB-1 and $\mathrm{OB}-2$ ) (table 4), along with concentrations of the pharmaceutical compounds (table 3). Qualityassurance samples and the raw sewage sample collected from the sewer on March 17, 2011, helped to ensure reliability of the results.

An additional site at the mouth of the Mill River was sampled in October and November to expand the scope of the assessment. The addition of this site and the data collected there contribute to a more complete understanding of the origin of potential sewage contaminants between Watershops Pond and the mouth of the river. There are three CSOs between the sites at Hancock Street and the river mouth. No acetaminophen or caffeine was detected in the October samples, but the sample collected at the mouth tested positive for the presence of both Bacteroidetes human-specific markers (table 4). FWA-1 and FWA-2 were detected in samples collected in October, but these results were too low to be quantified (table 4).

November 2010 results included detections of caffeine at the upriver and mid-reach sample sites, but the detections were at concentrations below the RL and therefore were not reliably quantified (table 3). Additionally, the Bacteroidetes group marker was detected, but other indicators were not detected (table 4). The samples collected from the mouth did not contain any detectable concentrations of any of the pharmaceutical compounds (table 3 ) but tested positive for the presence of the Bacteroidetes group marker and both Bacteroidetes human markers in PCR assays.

Indicator bacteria in Mill River samples collected during this low-flow study are likely the result of fecal contamination from warm-blooded animals. Avian species including pigeons, ducks, and geese were observed upriver from and around the sample sites. Other animal sources are likely and include wildlife and pet wastes. The increase in bacterial concentrations (CFU/100 mL) moving downriver from Watershops Pond to the mouth of the river indicate contamination along this reach of the river. The bacteria likely entered the river from nonpoint sources, which may include human sources. Additionally, wastewater constituents, including harmful bacteria, may enter the river from CSOs during storms and remain in the downriver environment for an extended period (Flint, 1987; van Elsas and others, 2011; Byappanahalli and others, 2012). 


\section{Conclusions}

The Mill River component of the Tri-State Connecticut River Targeted Watershed Initiative was performed by the U.S. Geological Survey in cooperation with the Pioneer Valley Planning Commission and the U.S. Environmental Protection Agency. A longitudinal approach was used to address water quality under low-flow conditions at three sites along the lower, urban reach of the Mill River in Springfield, Massachusetts, during summer and fall 2010 and March 2011. The highly urbanized tributaries in this river system are typical of those in cities along main stems of major rivers in the eastern United States. In past studies of similar locations, undocumented sources of wastewater were found to contribute measurable amounts of sewage constituents to rivers even during low-flow conditions.

However, the results of this study do not support the hypothesis that aging sewer lines or combined sewer overflow (CSO) infrastructure leak into the Mill River as tested during the low-flow conditions during sampling for this study. None of the results from Mill River samples offer conclusive evidence of the presence of sewage. Some low-level detections of pharmaceutical compounds, other man-made chemicals, and bacteria suggest an upstream, nonpoint source.

Bacteria in the Mill River upriver of CSO sites likely enter the river as nonpoint source contamination from mammalian and avian species but may also come from effluent from onsite septic systems or leakage from sewer lines. Indicators of sewage detected at low concentrations below CSOs during low-flow conditions may be the result of (1) contaminants lingering in the river after CSO discharge events have ended, (2) wastewater from leakage of untreated sewage from aging infrastructure or onsite septic systems, and (3) undocumented nonpoint sources such as wildlife or domestic animals.

\section{References Cited}

Barnes, K.K., Kolpin, D.W., Furlong, E.T., Zaugg, S.D., Meyer, M.T., and Barber, L.B., 2008, A national reconnaissance of pharmaceuticals and other organic wastewater contaminants in the United States-I. Groundwater: Science of the Total Environment, v. 402, no. 2-3, p. 192-200. [Also available at https://doi.org/10.1016/j.scitotenv.2008.04.028.]

Bauer, F., 1975, At the crossroads - Springfield, Massachusetts, 1636-1975: Springfield, Mass., U.S.A. Bicentennial Committee of Springfield, $157 \mathrm{p}$.

Benotti, M.J., Trenholm, R.A., Vanderford, B.J., Holady, J.C., Stanford, B.D., and Snyder, S.A., 2009, Pharmaceuticals and endocrine-disrupting compounds in U.S. drinking water: Environmental Science \& Technology, v. 43, no. 3, p. 597-603. [Also available at https://doi.org/10.1021/ es801845a.]
Bernhard, A.E., and Field, K.G., 2000a, A PCR assay to discriminate human and ruminant feces on the basis of host differences in Bacteroidetes-Prevotella genes encoding 16S rRNA: Applied and Environmental Microbiology, v. 66 , no. 10 , p. 4571-4574. [Also available at https://doi. org/10.1128/AEM.66.10.4571-4574.2000.]

Bernhard, A.E., and Field, K.G., 2000b, Identification of nonpoint sources of fecal pollution in coastal waters by using host-specific $16 \mathrm{~S}$ ribosomal DNA genetic markers from fecal anaerobes: Applied and Environmental Microbiology, v. 66, no. 4, p. 1587-1594. [Also available at https://doi.org/10.1128/AEM.66.4.1587-1594.2000.]

Breault, R.F., Sorenson, J.R., and Weiskel, P.K., 2002, Streamflow, water quality, and contaminant loads in the lower Charles River Watershed, Massachusetts, 19992000: U.S. Geological Survey Water-Resources Investigations Report 2002-4137, 131 p. [Also available at https://pubs.er.usgs.gov/publication/wri024137.]

Brown, C.J., and Trombley, T.J., 2009, Organic compounds in Running Gutter Brook water used for public supply near Hatfield, Massachusetts, 2003-05: U.S. Geological Survey Fact Sheet 2009-3076, 6 p. [Also available at https://doi.org/10.3133/fs20093076.]

Byappanahalli, M.N., Nevers, M.B., Korajkic, A., Staley, Z.R., and Harwood, V.J., 2012, Enterococci in the Environment: Microbiology and Molecular Biology Reviews, v. 76, no. 4, p. 685-706. [Also available at https://doi.org/10.1128/ MMBR.00023-12.]

Cantwell, M.G., Wilson, B.A., Zhu, J., Wallace, G.T., King, J.W., Olsen, C.R., Burgess, R.M., and Smith, J.P., 2010, Temporal trends of triclosan contamination in dated sediment cores from four urbanized estuaries-Evidence of preservation and accumulation: Chemosphere, v. 78, no. 4, p. 347-352. [Also available at https://doi.org/10.1016/j. chemosphere.2009.11.021.]

Childress, C.J.O., Foreman, W.T., Connor, B.F., and Maloney, T.J., 1999, New reporting procedures based on longterm method detection levels and some considerations for interpretations of water-quality data provided by the U.S. Geological Survey National Water Quality Laboratory: U.S. Geological Survey Open-File Report 99-193, 19 p. [Also available at https://pubs.er.usgs.gov/publication/ofr99193.]

Connecticut Department of Environmental Protection, 2011, State of Connecticut integrated water quality reportFinal-May 31, 2011: Hartford, Conn., Bureau of Water Management, Planning Division, 403 p. 
Del Rosario, K.L., Mitra, S., Humphrey, C.P., Jr., and O’Driscoll, M.A., 2014, Detection of pharmaceuticals and other personal care products in groundwater beneath and adjacent to onsite wastewater treatment systems in a coastal plain shallow aquifer: Science of the Total Environment, v. 487, p. 216-223. [Also available at https://doi.org/10.1016/j.scitotenv.2014.03.135.]

Duerring, C., Beskenis, J., Chase, R., Dunn, W., Tang, J., Stoner, R., Pancorbo, O., Waldron, M.C., and Sorenson, J., 2010, Enhancing the bacterial source tracking toolboxA collaborative approach:, Massachusetts Department of Environmental Protection report 83-AC3, 61 p., accessed February 24, 2016, at http://archives.lib.state.ma.us/ handle/2452/264436.

Flint, K.P., 1987, The long-term survival of Escherichia coli in river water: The Journal of Applied Bacteriology, v. 63, no. 3, p. 261-270. [Also available at https://doi.org/10.1111/j.1365-2672.1987.tb04945.x.]

Focazio, M.J., Kolpin, D.W., Barnes, K.K., Furlong, E.T., Meyer, M.T., Zaugg, S.D., Barber, L.B., and Thurman, M.E., 2008, A national reconnaissance for pharmaceuticals and other organic wastewater contaminants in the United States-II) Untreated drinking water sources: Science of the Total Environment, v. 402, no. 2-3, p. 201-216. [Also available at https://doi.org/10.1016/j.scitotenv.2008.02.021.]

Fono, L.J., Kolodziej, E.P., and Sedlak, D.L., 2006, Attenuation of wastewater-derived contaminants in an effluentdominated river: Environmental Science \& Technology, v. 40, no. 23 , p. $7257-7262$. [Also available at https://doi.org/10.1021/es061308e.]

Fono, L., and Sedlak, D.L., 2005, Use of the chiral pharmaceutical propranolol to identify sewage discharges into surface waters: Environmental Science \& Technology, v. 39, no. 23 , p. 9244-9252. [Also available at https://doi.org/10.1021/es047965t.]

Furlong, E.T., Werner, S.L., Anderson, B.D., and Cahill, J.D., 2008, Determination of human-health pharmaceuticals in filtered water by chemically modified styrene-divinylbenzene resin-based solid-phase extraction and highperformance liquid chromatography/mass spectrometry: U.S. Geological Survey Techniques and Methods, book 5, chap. B5, 56 p. [Also available at https://pubs.er.usgs.gov/ publication/tm5B5.]

Garbarino, J.R., Kanagy, L.K., and Cree, M.E., 2006, Determination of elements in natural-water, biota, sediment, and soil samples using collision/reaction cell inductively coupled plasma-mass spectrometry: U.S. Geological Survey Techniques and Methods, book 5, chap. B1, 88 p. [Also available at https://pubs.er.usgs.gov/publication/tm5B1.]
Kolpin, D.A., Furlong, E.T., Meyer, M.T., Thurman, E.M., Zaugg, S.D., Barber, L.B., and Buxton, H.T., 2002, Pharmaceuticals, hormones, and other wastewater organic contaminants in U.S. streams 1999-2000-A National reconnaissance: Environmental Science \& Technology, v. 36, no. 6, p. 1202-1211. [Also available at https://doi.org/10.1021/ es011055j.]

Kumar, A., Chang, B., and Xagoraraki, I., 2010, Human health risk assessment of pharmaceuticals in water-Issues and challenges ahead: International Journal of Environmental Research and Public Health, v. 7, no. 11, p. 3929-3953. [Also available at https://doi.org/10.3390/ijerph7113929.]

Massey, A.J., and Waldron, M.C., 2011, Pharmaceutical compounds in Merrimack River water used for public supply, Lowell, Massachusetts, 2008-09: U.S. Geological Survey Scientific Investigations Report 2011-5192, 14 p. [Also available at http://pubs.usgs.gov/sir/2011/5192.]

Musolff, A., Leschik, S., Reinstorf, F., Strauch, G., and Schirmer, M., 2010, Micropollutant loads in the urban water cycle: Environmental Science \& Technology, v. 44, no. 13, p. 4877-4883. [Also available at https://doi.org/10.1021/ es903823a.]

Myers, D.N., Stoeckel, D.M., Bushon, R.N., Francy, D.S., and Brady, A.M.G., 2007, Fecal indicator bacteria (ver. 2.0, February 2007): U.S. Geological Survey Techniques of WaterResources Investigations, book 9, chap. A7, section 7.1, 73 p., accessed July 26, 2010, at http://pubs.water.usgs.gov/ twri9A/.

Phillips, P., and Chalmers, A., 2009, Wastewater effluent, combined sewer overflows, and other sources of organic compounds to Lake Champlain: Journal of the American Water Resources Association, v. 45, no. 1, p. 45-57. [Also available at https://doi.org/10.1111/j.1752-1688.2008.00288.x.]

Phillips, P.J., Chalmers, A.T., Gray, J.L., Kolpin, D.W., Foreman, W.T., and Wall, G.R., 2012, Combined sewer overflows-An environmental source of hormones and wastewater micropollutants: Environmental Science \& Technology, v. 46, no. 10, p. 5336-5343. [Also available at https://doi.org/10.1021/es3001294.]

Phillips, P.J., Schubert, C., Argue, D., Fisher, I., Furlong, E.T., Foreman, W., Gray, J., and Chalmers, A., 2015, Concentrations of hormones, pharmaceuticals and other micropollutants in groundwater affected by septic systems in New England and New York: Science of the Total Environment, v. 512-513, p. 43-54. [Also available at https://doi.org/10.1016/j.scitotenv.2014.12.067.]

Pioneer Valley Planning Commission, 2005a, Combined sewer overflows (CSOs) and our rivers: Pioneer Valley Planning Commission CSO Fact Sheet 1, 15 p. 
Pioneer Valley Planning Commission, 2005b, Progress made to date: Pioneer Valley Planning Commission CSO Fact Sheet 4, 4 p.

Poiger, T., Field, J.A., Field, T.M., and Giger, W., 1996, Occurrence of fluorescent whitening agents in sewage and river water determined by solid-phase extraction and high-performance liquid chromatography: Environmental Science \& Technology, v. 30, no. 7, p. 2220-2226. [Also available at https://doi.org/10.1021/es950593r.]

Radke, M., Ulrich, H., Wurm, C., and Kunkel, U., 2010, Dynamics and attenuation of acidic pharmaceuticals along a river stretch: Environmental Science \& Technology, v. 44, no. 8, p. 2968-2974. [Also available at https://doi.org/10.1021/es903091z.]

Scott, T.M., Jenkins, T.M., Lukasik, J., and Rose, J.B., 2005, Potential use of a host associated molecular marker in Enterococcus faecium as an index of human fecal pollution: Environmental Science \& Technology, v. 39, no. 1, p. 283287. [Also available at https://doi.org/10.1021/es035267n.]

Smith, K.P., 2008, Hydrologic, water-quality, and meteorological data for the Cambridge, Massachusetts, drinkingwater source area, water year 2006: U.S. Geological Survey Open-File Report 2008-1175, 164 p. [Also available at https://pubs.er.usgs.gov/publication/ofr20081175.]

Springfield Water and Sewer Commission, 2012, Combined Sewer Overflow (CSO) and Wastewater Capital Improvement Plan (CIP): Springfield Water and Sewer Commission summary sheet, $4 \mathrm{p}$.

Tang, R.J., Waldron, M.C., Breault, R.F., Weiskel, P.K., Stoner, R.E., DiBara, M., Dunn, W., Duerring, C., Beskenis, J., Chase, R.F., DiPietro, P., Callaghan, T., Celona, M., Gray, D.J., and Pancorbo, O.C., 2006, Assessment of sewage pollution in Massachusetts rivers and beaches using a sewage-specific marker PCR assay targeting a putative virulence factor (esp gene) in Enterococcus faecium: American Society for Microbiology Annual General Meeting, 106th, Orlando, Florida, poster Q-219, accessed February 24, 2016, at http:/www.mass.gov/eea/docs/dep/about/ organization/asm2006.pdf.
U.S. Environmental Protection Agency, 2000, Improved enumeration methods for the recreational water quality indicators-Enterococci and Escherichia coli: U.S. Environmental Protection Agency EPA/821/R-97/004, 49 p.

U.S. Environmental Protection Agency, 2002, Onsite wastewater treatment systems manual: U.S. Environmental Protection Agency EPA/625/R-00/008, 369 p.

U.S. Environmental Protection Agency, 2009, NPDES Permit MA0103331: U.S. Environmental Protection Agency National Pollutant Discharge Elimination System permit, 12 p., accessed February 18, 2016, at http://www3.epa.gov/ region1/npdes/permits/2009/finalma0103331permit.pdf.

U.S. Environmental Protection Agency, 2014, National summary of impaired waters and TMDL information: U.S. Environmental Protection Agency web page, accessed February 18, 2016, at http://iaspub.epa.gov/waters10/ attains_nation_cy.control\%3Fp_report_type $\% 3 \mathrm{DT}$.

U.S. Geological Survey, variously dated, National field manual for the collection of water-quality data: U.S. Geological Survey, Techniques of Water-Resources Investigations, book 9, chaps. A1-A9. [Also available at https://pubs.water.usgs.gov/twri9A.]

van Elsas, J.D., Semenov, A.V., Costa, R., and Trevors, J.T., 2011, Survival of Escherichia coli in the environment—Fundamental and public health aspects: International Society for Microbial Ecology Journal, v. 5, no. 2, p. 173-183. [Also available at https://dx.doi.org/10.1038\%2Fismej.2010.80.]

Wilde, F.D., Radtke, D.B., Gibs, Jacob, and Iwatsubo, R.T., eds., 2004 [with updates through 2009], Processing of water samples (ver. 2.2): U.S. Geological Survey Techniques of Water-Resources Investigations, book 9, chap. A5, accessed January 19, 2010, at http:/water.usgs.gov/owq/ FieldManual/chapter5/pdf/chap5_2-2009.pdf. 
For more information about this report, contact: Director, New England Water Science Center U.S. Geological Survey 331 Commerce Way, Suite 2

Pembroke, NH 03275

dc_nweng@usgs.gov or visit our website at https://newengland.water.usgs.gov

Publishing support provided by the Pembroke Publishing Service Center 
